\title{
Circulation at the western boundary of the South and Equatorial Atlantic: Exchanges with the ocean interior
}

\author{
by Nicolas Wienders ${ }^{1}$, Michel Arhan ${ }^{1}$ and Herlé Mercier ${ }^{1}$
}

\begin{abstract}
Data from a hydrographic section carried out in January-March 1994 offshore from the eastern coast of South America from 50S to 10N, are used to quantify the full-depth exchanges of water between the western boundary currents and the ocean interior. In the upper and intermediate layers, the westward transport associated with the southern branch of the South Equatorial Current was $49 \mathrm{~Sv}$ at the time of the cruise. The transports of the central and northern branches in the upper $200 \mathrm{~m}$ were $17 \mathrm{~Sv}$ and $12 \mathrm{~Sv}$, respectively. After subtraction of the parts that recirculate in the subtropical, subequatorial, and equatorial domains, the fraction of the South Equatorial Current that effectively contributes to the warm water export to the North Atlantic is estimated at $18 \mathrm{~Sv}$. The poleward boundary of the current southern branch is at $31 \mathrm{~S}$ through the whole thickness of the subtropical gyre, but the latitude of the northern boundary varies from $7^{\circ} 30^{\prime} \mathrm{S}$ at the surface to $27 \mathrm{~S}$ at $1400 \mathrm{~m}$ depth. The estimated latitude of its bifurcation into the Brazil Current and North Brazil Undercurrent also varies downward from about $14 \mathrm{~S}$ at the surface to $28 \mathrm{~S}$ at a depth of $600 \mathrm{~m}$.

In the North Atlantic Deep Water, eastward flows exceeding $10 \mathrm{~Sv}$ are observed at $3^{\circ}-4^{\circ}$ of latitude in both hemispheres, at $10 \mathrm{~S}$, and at $34 \mathrm{~S}-30 \mathrm{~S}$. Between $4 \mathrm{~S}$ and $17 \mathrm{~S}$, a net westward flow with an estimated transport of $19 \mathrm{~Sv}$ reinforces the southward deep western boundary current. Cyclonic circulations of Antarctic Bottom Water along the western boundaries of the Argentine and Brazil basins have amplitudes of $15 \mathrm{~Sv}$ and $13 \mathrm{~Sv}$, respectively, exceeding those of the interbasin exchanges. The net alongshore transport of this water mass between the hydrographic section and the continental slope reverses to a southward direction from $13 \mathrm{~S}$ to $27 \mathrm{~S}$, probably in relation with an eastward shift of the equatorward near-bottom boundary current at these latitudes.
\end{abstract}

\section{Introduction}

Viewed in the framework of the oceanic thermohaline circulation, the system of western boundary currents of the South and Equatorial Atlantic serves a clear-cut purpose first brought to light by Stommel (1957). At the upper levels, it collects the Central and Intermediate Waters bound for the North Atlantic from the ocean interior. Deeper in the water column, it conveys the North Atlantic Deep Water southward and distributes it to the open ocean. This function could be fulfilled by a simple flow structure, were it not for the wind-driven contribution to the boundary currents, which Stommel showed to oppose the thermohaline contribution in the subtropics of the South Atlantic. This counteraction

1. Laboratoire de Physique des Océans, IFREMER Centre de Brest, B.P. 70, 29280 Plouzané, France. email: michel.arhan@ifremer.fr 
causes several flow reversals in the meridional and vertical distributions of the boundary currents. From south to north in the upper ocean, these currents include the equatorward Falkland Current in the subpolar domain, the poleward Brazil Current in the subtropics, and the ensemble formed by the northward North Brazil Undercurrent, North Brazil Current, and Guiana Current in the subequatorial and equatorial regions. Vertically, the barotropic character of the Falkland Current contrasts with a higher mode structure in the subtropics.

Our present knowledge of the western boundary currents in the South and Equatorial Atlantic mainly rests on local studies, most of which used geostrophic computations, and a few were based on direct measurements. ${ }^{2}$ Although these regional studies progressively build up an ensemble view of the boundary flow system, their gathering also reveals a scatter of the transport estimates at places. Time variations are probably a cause of the disparities. Another cause lies in the dependence of the vertical structure of the flow on latitude. As an example, the transport estimates of the Falkland Current at $46 \mathrm{~S}$ range from $10 \mathrm{~Sv}\left(1 \mathrm{~Sv}=10^{6} \mathrm{~m}^{3} \mathrm{~s}^{-1}\right)$ when a reference level at intermediate depth is used, to more than $80 \mathrm{~Sv}$ when the barotropic character of the current is taken into account (Peterson, 1992). In the subtropical domain, the thickness increase of the poleward flow, from about zero near $10 \mathrm{~S}$ to more than $3000 \mathrm{~m}$ at $38 \mathrm{~S}$, causes an ambiguity in the very definition of the Brazil Current.

Current meter arrays have been deployed at the western boundary of the South Atlantic during the World Ocean Circulation Experiment (WOCE). These measurements (at $\sim 40 \mathrm{~S}$, Vivier and Provost, 1999; at 29S, Hogg et al., 1999; at 18S, Weatherly et al., 2000) generally confirm the high side geostrophic estimates, and reveal a significant timevariability. Acoustic Doppler Current Profiler (ADCP) data and current meter time series have also been used at the equatorial western boundary (Stramma et al., 1995; Schott et al., 1993; Fischer and Schott, 1997; Bourlès et al., 1999; Hall et al., 1997; Johns et al., 1990, 1993, 1998). In this region, however, the connection of the boundary currents with the equatorial currents and their high temporal variability make it difficult to characterize each of them by a single transport value.

There have been only a few comprehensive studies of the system of western boundary currents in the South Atlantic since Stommel's (1957) first determination of a schematic distribution of their transports. Veronis (1978) proposed a more elaborate version of the transport distribution, which displays plausible characteristics of the Brazil Current (origin near $12 \mathrm{~S}$, maximum transport around $40 \mathrm{~Sv}$ ) but does not show the northward crossequatorial flow. Reid's (1989) surface-to-bottom integrated transports provide the approximate latitudinal span of the Brazil Current (12S to 40S), and show magnitudes of about $40 \mathrm{~Sv}$ for this current and the Falkland Current. These studies, however, only provide the gross features of the transport distribution along the boundary. Onken (1994) provides a refined meridional structure, but only considers the upper layer.

2. A list of observed upper-ocean western boundary current transports in the Atlantic may be found in Onken (1994). 

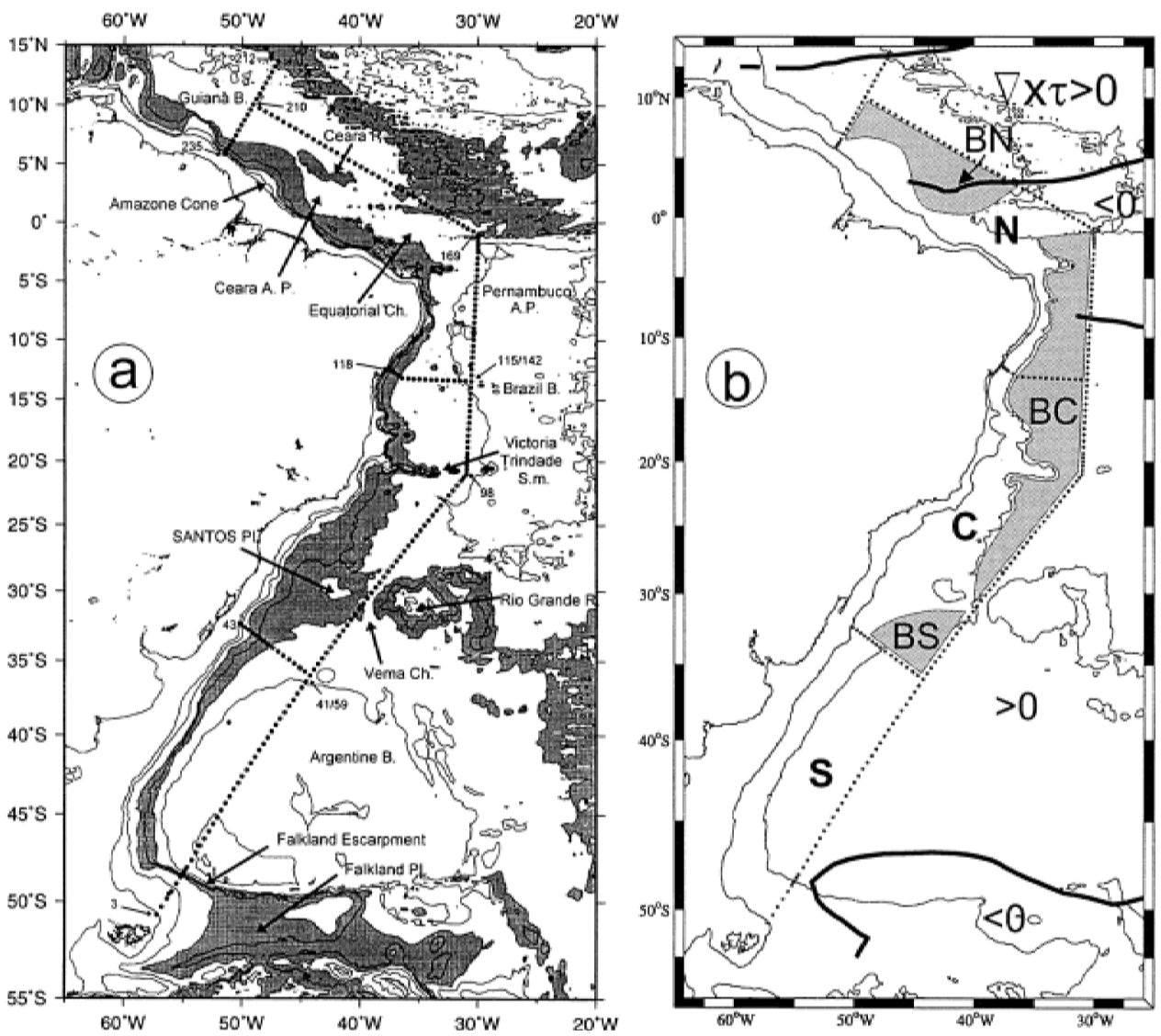

Figure 1. (a) Map of the hydrographic survey CITHER-2, showing the bathymetric setting. Isobaths $200 \mathrm{~m}$ and multiples of $1000 \mathrm{~m}$ are reported. Shading marks the depths between $2000 \mathrm{~m}$ and $4000 \mathrm{~m}$. AP stands for Abyssal Plain, B for Basin, Ch for Channel, Pl for Plateau, R for Rise, and Sm for Seamounts. (b) Map of the hydrographic survey showing the boxes where property conservation constraints were imposed. Boxes S, C, and $\mathrm{N}$ are full-depth boxes limited by the hydrographic lines and the coast. BS, BC, and BN (shaded) are "bottom" boxes used for the abyssal waters blocked by the Santos Plateau and the Equatorial Channel. The lines of vanishing wind stress curl are superimposed(1992-1998 averages from the ERS microwave scatterometers).

As part of WOCE, a hydrographic section was realized parallel to the coast of South America from $51 \mathrm{~S}$ to $10 \mathrm{~N}$, at a nominal distance of $600 \mathrm{~km}$ from the continental slope. This section and three other shorter lines to the continental shelf break (Fig. 1a) are used in this study for a quantification of the boundary currents over this wide latitudinal range and from surface to bottom. The transports are determined from an inversion procedure which requires that the absolute velocities remain close to a reasonable a priori solution, and satisfy conservation constraints in boxes delimited by the hydrographic lines and the coast, with a prescribed uncertainty. In this paper we present the inversion method and the 
transports across the quasi-meridional line, which we regard as a measure of the exchanges between the boundary region and the open ocean. We begin with a brief presentation of the data and main characteristics of the region. The method of determination of the absolute velocities is described, followed by a discussion of the exchanges of upper and intermediate water, deep water, and bottom water, with the ocean interior. The meridional integration of the transports provides the alongshore net flow between the quasi-meridional line and the coast. In a companion paper, we use this result and the transports across the transverse lines for an analysis of the vertical and meridional structures of the boundary currents.

\section{The data and main characteristics of the region}

\section{a. Data}

The hydrographic and tracer measurements were carried out from January 4th to March 21st, 1994, during cruise CITHER ${ }^{3}-2$ of the WOCE/France programme. A presentation of the cruise and description of the data may be found in Le Groupe CITHER-2 $(1995,1996)$. Briefly, 235 full-depth stations were realized from the R/V Maurice Ewing with a nominal station spacing of $30 \mathrm{NM}$ that was decreased near the equator and over steep bathymetry. In the following, we refer to the quasi-meridional line as to A17, its WOCE denomination. The three transverse sections are referred to as $35 \mathrm{~S}, 13 \mathrm{~S}$, and $10 \mathrm{~N}$, as a reminder of their nominal latitudes. We identify the three boxes delimited by the hydrographic lines and the coast as the southern (S), central (C) and northern (N) boxes (Fig. 1b).

\section{b. Bathymetry}

The southernmost station of A17 is just to the north of the Falkland Islands, north of which the line intersects the Falkland Escarpment, then the trough of the Argentine Basin, with depths greater than $6000 \mathrm{~m}$ at $47 \mathrm{~S}-45 \mathrm{~S}$ (Fig. 1a). North of this latitude, the bathymetry progressively rises to $3700 \mathrm{~m}$ at the Santos Plateau $\left(31^{\circ} 15^{\prime} \mathrm{S}\right)$. Near $30^{\circ} 40^{\prime} \mathrm{S}$ the cruise track cuts the 4650 m-deep Vema Channel (Zenk et al., 1993). In the Brazil Basin, the line shows two changes of orientation, one at 21S near the Vitoria-Trindade Ridge, and the other at 1S. North of this latitude, A17 is oriented northwestward along the northern side of the Equatorial Channel, a 4350 m-deep passage between the Brazil and Guiana Basins (McCartney and Curry, 1993), then to the north of the Ceara Rise into the Guiana Basin.

\section{c. Meteorologicalforcing}

The lines of zero wind stress curl are shown in Figure 1b. Two regions of negative curl, corresponding approximately to cyclonic circulations in the southern subpolar and subequatorial domains, are present on either side of the subtropical gyre. In the equatorial region, a system of zonal flows of both directions is connected to the western boundary currents. The 
domain of positive curl centered around $10 \mathrm{~N}$ corresponds to the cyclonic northern subequatorial gyre. In the present diagnostic study, the effect of the wind on the volume budget computations only occurs through the Ekman transports across the hydrographic lines. These were computed using the wind stress values from the ERS ${ }^{4}$ scatterometer at the time of the cruise.

Oceanic western boundaries are locations of intense heat exchanges between the ocean and the atmosphere. A map of the averaged heat flux for the years 1993-1994, constructed from the ECMWF ${ }^{5}$ data base (not shown), reveals that the ocean gains heat from the atmosphere over most of the western boundary of the South and Equatorial Atlantic, with peak values exceeding $50 \mathrm{~W} \mathrm{~m}^{-2}$ near $22 \mathrm{~S}$ and over the northern reaches of the Falkland Current. An exception to the net oceanic heat gain is the latitude domain $25 \mathrm{~S}-40 \mathrm{~S}$, where the warm waters of the Brazil Current flow under a relatively cold air. This averaged situation, however, masks intense seasonal variations with crest-to-trough amplitudes of $250 \mathrm{~W} \mathrm{~m}^{-2}, 100 \mathrm{~W} \mathrm{~m}^{-2}$, and $30 \mathrm{~W} \mathrm{~m}^{-2}$ over the surfaces of boxes $\mathrm{S}, \mathrm{C}$, and $\mathrm{N}$, respectively.

\section{d. Water masses}

The distribution of water masses along A17 was described in Mémery et al. (2000). It is illustrated in Figure 2a from the vertical section of dissolved oxygen. Also shown are isopycnals ${ }^{6}$ defining water mass layers used for the volume budget calculations. These isopycnals were chosen to encompass the water mass tracer extrema. They are given in Table 1 for the South Atlantic Central Water (SACW), the Antarctic Intermediate Water (AAIW), the Upper Circumpolar Water (UCPW), the North Atlantic Deep Water (NADW), and the Antarctic Bottom Water (AABW). Due to the important latitudinal extent, some isopycnal limits had to be modified at the box boundaries. The NADW was subdivided into its upper, middle, and lower components (UNADW, MNADW, LNADW) in box N. The same layer is occupied by circumpolar water, not NADW, at the southern end of box S. We use the usual name of AABW to designate the water present below the NADW, but recognize that this layer of «bottom» water is nearly $3000 \mathrm{~m}$ thick in the southwestern Argentine Basin (Fig. 2a). In boxes $\mathrm{S}$ and $\mathrm{C}$ we subdivide the AABW into its two components, the Lower Circumpolar Water (LCPW) and Weddell Sea Deep Water (WSDW).

\section{Determination of absolute velocities}

a. The inverse model formulation

The transports across the hydrographic lines were required to satisfy conservation constraints in the previously defined boxes, and in three additional bottom boxes (Fig. 1b)

4. ERS: European Remote sensing Satellite.

5. ECMWF: European Centre for Medium-range Weather Forecasting.

6. The densities are potential densities referred to multiples of $1000 \mathrm{dbar}\left(\sigma_{\theta}, \sigma_{1}, \sigma_{2}, \ldots\right)$. They were computed using the International Equation of State (EOS80) and their unit $\left(\mathrm{kg} \mathrm{m}^{-3}\right)$ is omitted hereafter in the paper. 

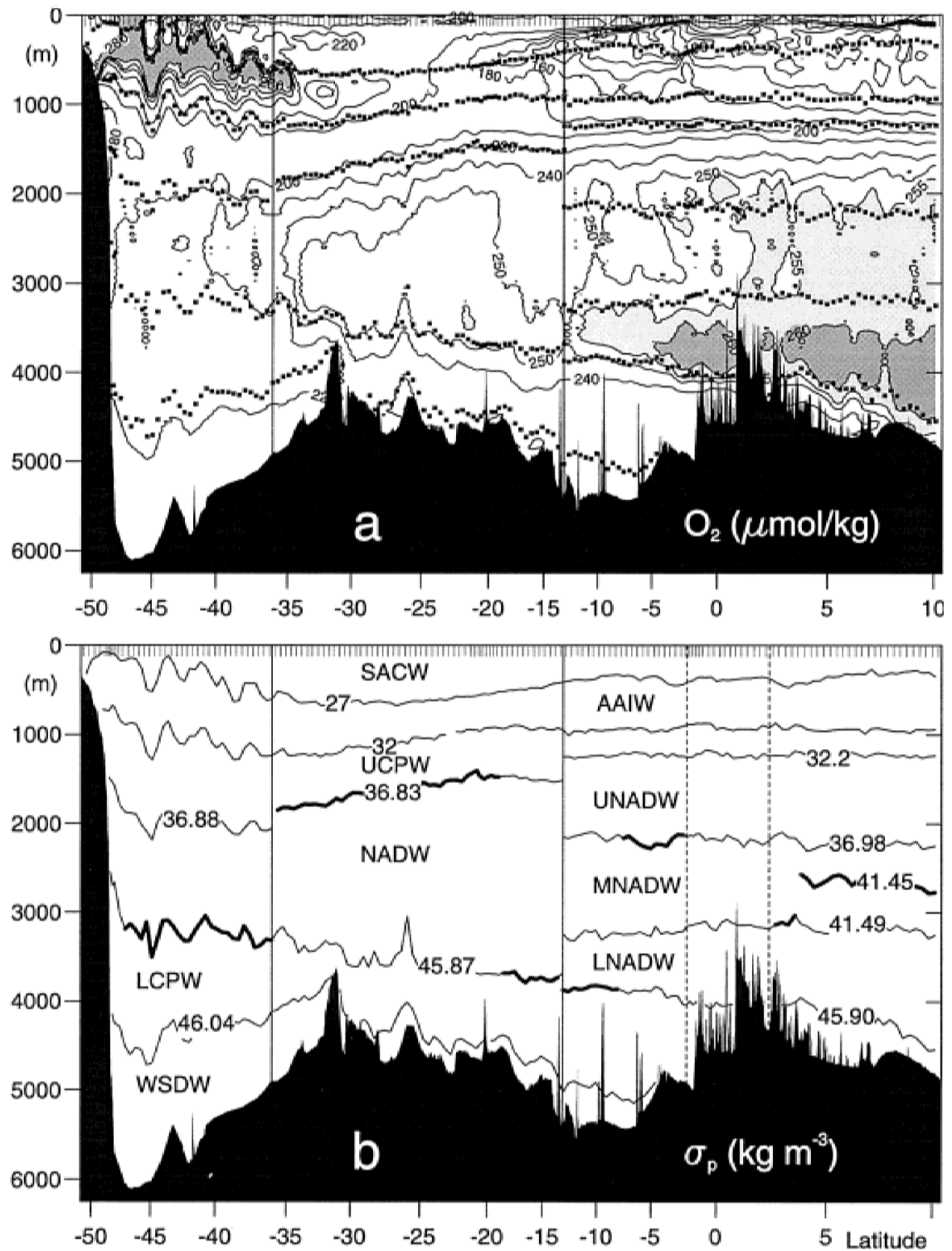

Figure 2. (a) Vertical distribution of dissolved oxygen along A17, with the isopycnal boundaries of the water mass layers superimposed (see Table 1). The two vertical lines mark the separation between boxes S, C and N. (b) Vertical section along A17 showing the water mass boundaries (light) and the a priori reference isopycnals of the inversion (bold). The bottom was used as a reference level to the south of $47^{\circ} 40^{\prime} \mathrm{S}$. The vertical broken lines at $2^{\circ} 30^{\prime} \mathrm{S}$ and $2^{\circ} 30^{\prime} \mathrm{N}$ show the ageostrophic equatorial band. 
Table 1. Water mass isopycnal layers used for the conservationconstraints in the hydrographicboxes

$\mathrm{S}, \mathrm{C}$ and $\mathrm{N}$ (Fig 1b). The potential densities, referred to multiples of $1000 \mathrm{dbar}$, are in $\mathrm{kg} \mathrm{m}^{-3}$.

\begin{tabular}{|c|c|c|c|c|c|c|}
\hline Water mass & \multicolumn{2}{|c|}{ S } & \multicolumn{2}{|c|}{$\mathrm{C}$} & \multicolumn{2}{|c|}{$\mathrm{N}$} \\
\hline SACW & Surface & $27.00 \sigma_{\theta}$ & Surface & $27.00 \sigma_{\theta}$ & Surface & $27.00 \sigma_{\theta}$ \\
\hline AAIW & $27.00 \sigma$ & $32.00 \sigma_{1}$ & $27.00 \sigma$ & $32.00 \sigma_{1}$ & $27.00 \sigma_{\theta}$ & $32.00 \sigma_{1}$ \\
\hline UCPW & $32.00 \sigma$ & $36.88 \sigma_{2}$ & $32.00 \sigma$ & $36.88 \sigma_{2}$ & $32.00 \sigma_{1}$ & $36.88 \sigma_{1}$ \\
\hline $\begin{array}{l}\text { NADW } \\
\text { Upper } \\
\text { Middle } \\
\text { Lower }\end{array}$ & $36.88 \sigma$ & $45.87 \sigma_{4}$ & $36.83 \sigma$ & $45.87 \sigma_{4}$ & $\begin{array}{l}32.20 \sigma_{1} \\
36.98 \sigma_{2} \\
41.49 \sigma_{3}\end{array}$ & $\begin{array}{l}36.98 \sigma_{2} \\
41.49 \sigma_{3} \\
45.90 \sigma_{4}\end{array}$ \\
\hline $\begin{array}{l}\text { AABW } \\
\text { LCPW }\end{array}$ & $45.87 \sigma$ & $46.04 \sigma_{4}$ & $45.87 \sigma$ & $46.04 \sigma_{4}$ & $45.90 \sigma_{4}$ & \\
\hline WSDW & $46.04 \sigma$ & Bottom & $46.04 \sigma$ & Bottom & & Bottom \\
\hline
\end{tabular}

laterally closed for the densest waters. These are box BS in the northern Argentine Basin for the water blocked northward by the Santos Plateau $\left(\sigma_{4}>46.06\right)$, box BC in the Brazil Basin for the water blocked northward by the Equatorial Channel $\left(\sigma_{4}>46.02\right)$, and box $\mathrm{BN}$ in the Guiana Basin in which we assumed an inflow of $2 \mathrm{~Sv}$ of AABW $\left(\sigma_{4}>45.90\right)$ from the Equatorial Channel (Hall et al., 1997). The conservation constraints, expressed using a set of unknowns gathered in a vector $\mathbf{X}$, constitute a linear system of equations $F . \mathbf{X}-A=0$. Following Tarentola and Valette (1982), a best estimate of $\mathbf{X}$ is sought, which minimizes the function

$$
S=\left(\mathbf{X}-\mathbf{X}_{0}\right)^{T} C_{0}^{-1}\left(\mathbf{X}-\mathbf{X}_{0}\right)+(F \mathbf{X}-A)^{T} C_{T}^{-1}(F \mathbf{X}-A),
$$

where the vector $\mathbf{X}_{0}$ contains a priori values of the unknowns, $C_{0}$ is the error covariance matrix of the unknowns, and $C_{T}$ the error covariance matrix of the constraints. In the minimization process, $C_{0}$ and $C_{T}$ control the deviations from $\mathbf{X}_{0}$ and the constraint residuals, respectively. $\mathbf{X}_{0}, C_{0}, F, C_{T}$ and $A$ are specified before inversion.

There are three types of unknowns to the problem:

(1) The velocity component $u_{b}$, normal to the hydrographic lines, at specified reference isopycnals of all station pairs located at latitudes higher than $2^{\circ} 30^{\prime} \mathrm{S}$ or $2^{\circ} 30^{\prime} \mathrm{N}$. At these station pairs the absolute velocity is determined as the sum of the reference velocity, the relative geostrophic velocity, and the Ekman velocity. The velocity at the deepest common level of a station pair is extended downward in the bottom triangle. There are 188 unknown reference velocities. 
Table 2. Choices of reference surfaces along A17 and the three transverse lines. A priori values of the reference level velocities are zero everywhere except at the southern end of A17 (latitude range $50^{\circ} 42^{\prime} \mathrm{S}-47^{\circ} 40^{\prime} \mathrm{S}$ ) where bottom velocities deduced from ship-borne ADCP measurements were used.

\begin{tabular}{|c|c|c|c|}
\hline Latitude & Reference surface & Longitude & Reference surface \\
\hline \multicolumn{2}{|c|}{ A17 } & \multicolumn{2}{|c|}{$35 \mathrm{~S}$} \\
\hline \multirow{11}{*}{$\begin{array}{c}50^{\circ} 42^{\prime} \mathrm{S}-47^{\circ} 40^{\prime} \mathrm{S} \\
47^{\circ} 40^{\prime} \mathrm{S}-36 \mathrm{~S} \\
36 \mathrm{~S}-19 \mathrm{~S} \\
19 \mathrm{~S}-8^{\prime} 30^{\prime} \mathrm{S} \\
8^{\circ} 30^{\prime} \mathrm{S}-2^{\prime} 30^{\prime} \mathrm{S} \\
2^{\circ} 30 \mathrm{~N}-3^{\prime} 20^{\prime} \mathrm{N} \\
3^{\circ} 20 \mathrm{~N}-10^{\prime} \mathrm{N}\end{array}$} & \multirow{11}{*}{$\begin{array}{l}\text { Bottom } \\
45.87 \sigma_{4} \\
36.83 \sigma_{2} \\
45.90 \sigma_{4} \\
36.98 \sigma_{2} \\
41.49 \sigma_{3} \\
41.45 \sigma_{3}\end{array}$} & $50^{\circ} 13^{\prime} \mathrm{W}-48^{\circ} 50^{\prime} \mathrm{W}$ & Bottom \\
\hline & & $48^{\circ} 50^{\prime} \mathrm{W}-44^{\circ} 15^{\prime} \mathrm{W}$ & $45.87 \sigma_{4}$ \\
\hline & & & \\
\hline & & \multicolumn{2}{|c|}{$13 \mathrm{~S}$} \\
\hline & & \multirow{2}{*}{$37^{\circ} 38^{\prime} \mathrm{W}-30^{\circ} 35^{\prime} \mathrm{W}$} & \multirow{2}{*}{$32.20 \sigma_{1}$} \\
\hline & & & \\
\hline & & \multicolumn{2}{|c|}{$10 \mathrm{~N}$} \\
\hline & & $51^{\circ} 29^{\prime} \mathrm{W}-50^{\circ} 20^{\prime} \mathrm{W}$ & $32.00 \sigma_{1}$ \\
\hline & & $50^{\circ} 20^{\prime} \mathrm{W}-49^{\circ} 50^{\prime} \mathrm{W}$ & $45.90 \sigma_{4}$ \\
\hline & & $49^{\circ} 50^{\prime} \mathrm{W}-48 \mathrm{~W}$ & $41.45 \sigma_{3}$ \\
\hline & & 48W-47W & Bottom \\
\hline
\end{tabular}

(2) The transports $T_{e q}$ perpendicular to A17 at each station pair in the equatorial band, for each of the seven layers of box $\mathrm{N}$. There are 119 unknown equatorial transports. Those of the SACW layer were given a priori values deduced from the shipborne ADCP. The others were set to zero. The uncertainties of the equatorial transports and reference velocity unknowns are given below.

(3) The vertical diffusivities $K_{v}$ at the layer interfaces. There are 19 such unknowns. $A$ priori values ranging from $1.10^{-4} \mathrm{~m}^{2} \mathrm{~s}^{-1}$ to $4.10^{-4} \mathrm{~m}^{2} \mathrm{~s}^{-1}$ from top to bottom, with uncertainties equal to half these values, were chosen in boxes $\mathrm{S}$ and $\mathrm{C}$ to account for an expected increase of mixing toward the bottom. Difficulties to solve the equations in box $\mathrm{N}$ led us to accept larger diapycnal transports. $K_{v}$ values of $10^{-3} \mathrm{~m}^{2} \mathrm{~s}^{-1}$ were chosen in this box.

\section{b. The a priori reference isopycnals}

The reference surfaces are reported in Table 2 and shown in Figures $2 b$ and 3(d,e,f). Where possible, we placed them at water mass boundaries, in such a way that the a priori transports inferred from the isopycnal slopes match the spreading directions suggested by the tracer fields. This proved problematic in two instances: along a part of the perimeter of box $\mathrm{N}$ (see below), and over some narrow fractions of the continental slope, where the current shows no reversal in the vertical. The region of the Falkland Current (south of $47^{\circ} 40^{\prime} \mathrm{S}$ in Fig. 2) comes under the latter case, with the additional particularity that significant velocities are expected down to the bottom (Peterson, 1992). There, the a priori absolute velocities were determined from the shipborne ADCP. 
North of the Falkland Current, vanishing reference velocities were chosen everywhere. The NADW/LCPW interface $\left(45.87 \sigma_{4}\right)$ was used as a reference isopycnal over the remainder of the eastern side of box $\mathrm{S}$. This choice (close to the $45.85 \sigma_{4}$ value of Peterson et al., 1996) is consistent with a near-bottom cyclonic circulation in the Argentine Basin (Coles et al., 1996), and an average eastward flow of the upper water masses. Proceeding northward, the high oxygen values $\left(>250 \mu \mathrm{mol} \mathrm{kg}^{-1}\right.$ ) between $34 \mathrm{~S}$ and $19 \mathrm{~S}$ in the NADW layer (Fig. 2a) mark an escape of this water from the boundary (e.g., Durrieu de Madron and Weatherly, 1994). As the intermediate waters at the same latitudes flow westward in the northern limb of the subtropical gyre (e.g.: Boebel et al., 1997), the reference isopycnal was placed at the UCPW/NADW interface $\left(36.83 \sigma_{2}\right)$ in this region. It was displaced to the $\mathrm{NADW} / \mathrm{AABW}$ interface $\left(45.87 \sigma_{4}\right.$ and $\left.45.90 \sigma_{4}\right)$ from $19 \mathrm{~S}$ to $8^{\circ} 30^{\prime} \mathrm{S}$, to account for a westward motion of bottom water suggested by an equatorward deepening of the deepest isopycnals.

North of $8^{\circ} 30^{\prime} \mathrm{S}$, narrow regions of steep isopycnal slopes at depth, associated with low values of the Coriolis parameter, left us with no other choice than a priori vanishing velocities at mid-depth, in order to keep the transports in the upper- and lowermost layers within realistic bounds. After trials, we retained the UNADW/MNADW boundary $\left(36.98 \sigma_{2}\right)$ between $8^{\circ} 30^{\prime} \mathrm{S}$ and $2^{\circ} 30^{\prime} \mathrm{S}$, and the isopycnal $41.45 \sigma_{3}$ within the MNADW to the north of $3^{\circ} 20^{\prime} \mathrm{N}$. In the narrow domain $2^{\circ} 30^{\prime} \mathrm{N}-3^{\circ} 20^{\prime} \mathrm{N}$, the proximity of the Mid-Atlantic Ridge, and ensuing weak cross-sectional flows of LNADW, led us to choose the LNADW/ MNADW interface.

Along 35S (Fig. 3a,d), the reference isopycnal was chosen at the separation between the equatorward current of AABW and the poleward flow of NADW $\left(45.87 \sigma_{4}\right)$. Along $13 \mathrm{~S}$ (Fig. $3 \mathrm{~b}, \mathrm{e})$ we placed it at the UCPW/NADW boundary $\left(32.2 \sigma_{1}\right)$, close to previous choices of $32.15 \sigma_{1}$ by Stramma (1991) and $1000 \mathrm{~m}$ by Silveira et al. (1994). The tracer patterns along $10 \mathrm{~N}$ (Fig. $3 \mathrm{c}$ ) suggest a columnar circulation that was found to match a neighboring lowered ADCP section realized along 7³0' $\mathrm{N}$ in April 1996 (Equipe ETAMBOT, 1997). Our choice of an a priori solution along $10 \mathrm{~N}$ and west of $48 \mathrm{~W}$ (Fig. 3f) was guided by these direct measurements. East of this longitude, lower oxygen values and eastward deepening isopycnals suggest a full-depth northwestward flow not connected to the boundary currents. This barotropic character of the flow was reproduced by referencing the velocities at the bottom. The vertical dotted line at $49 \mathrm{~W}$ in Figure $3 \mathrm{f}$ separates the part of $10 \mathrm{~N}$ which contributes to box $\mathrm{N}$, from that which does not. The $10 \mathrm{~N}$ transports were deduced from the post-inversion velocities west of $49 \mathrm{~W}$, and are directly issued from the above choice of reference surfaces to the east of this longitude.

\section{c. The constraints and their uncertainties}

The model uses three types of constraints: (1) Surface-to-bottom volume conservation in boxes S, C, and N. (2) Volume conservation in all layers of the same boxes (Table 1) and in the unique (bottom) layers of boxes BS, BC and BN. We only included the lateral advection terms in these equations, leaving the vertical advection to be accounted for by the 

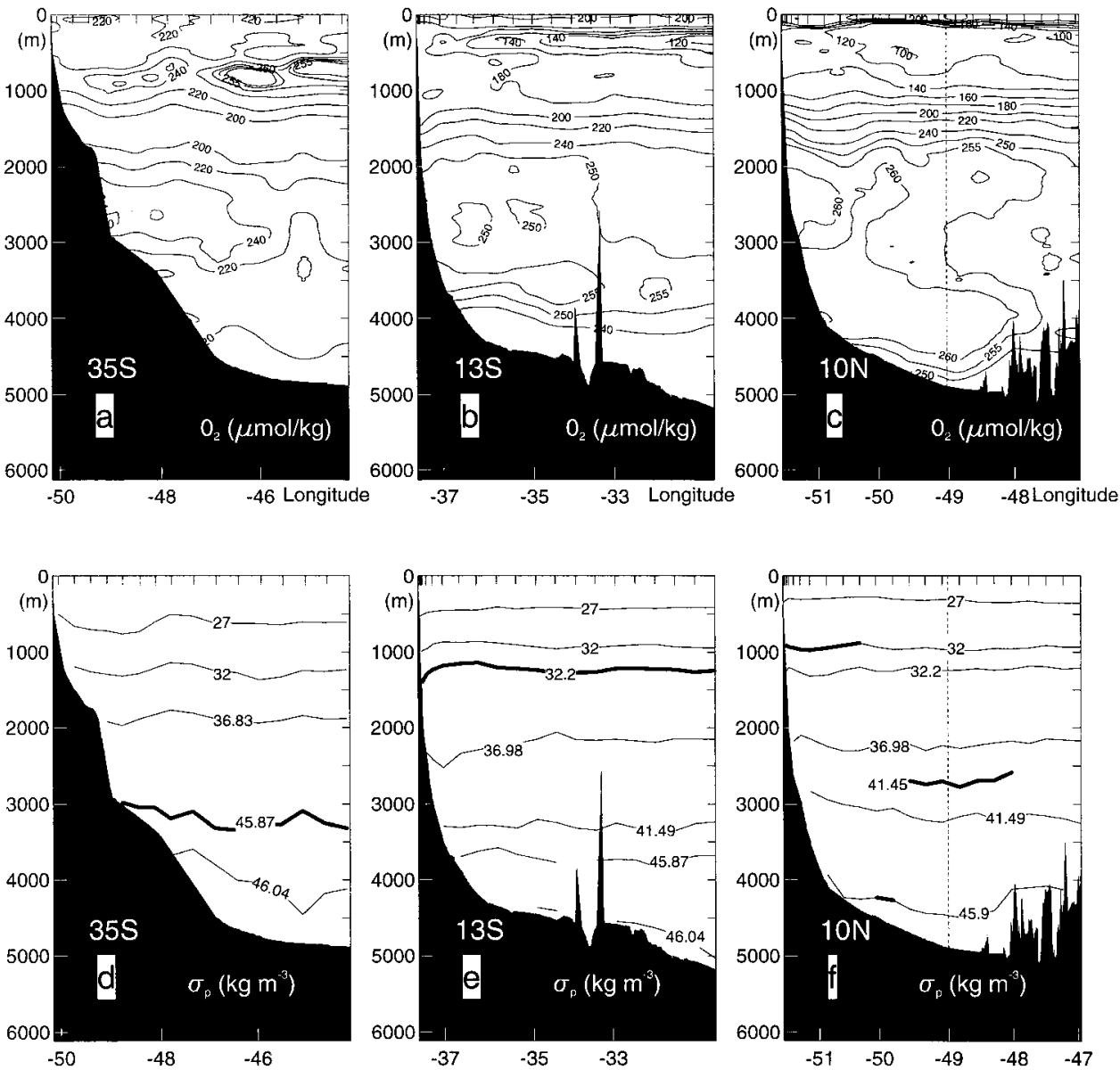

Figure 3. (a), (b), (c) Vertical distributions of dissolved oxygen along the three transverse sections $35 \mathrm{~S}, 13 \mathrm{~S}$ and $10 \mathrm{~N}$. The vertical line on the latter shows the intersection with A17. (d), (e), (f) Water mass boundaries and a priori reference levels (bold) along the three transverse lines. The bottom was used as a reference level to the west of $49 \mathrm{~W}$ along $35 \mathrm{~S}$ (d), and to the east of $48 \mathrm{~W}$ along $10 \mathrm{~N}(\mathrm{f})$.

constraint uncertainties. (3) Tracer conservations in the same layers and boxes. The conserved tracers are heat, salt, silicate, and the parameters NO and PO proposed by Broecker (1974), which are linear combinations of the dissolved oxygen, nitrate, and phosphate values. We used the relations $\mathrm{NO}=\mathrm{O}_{2}+9.4 \mathrm{NO}_{3}$ and $\mathrm{PO}=\mathrm{O}_{2}+175 \mathrm{PO}_{4}$ (X. A. Alvarez-Salgado pers. comm.). The tracer equations include vertical advection and diffusion at the layer interfaces. Lateral diffusion is neglected.

The equations of the upper layer and full-depth constraints also include the alongshore shelf transports, the Amazon River volume and tracer discharge (for box N), and the air-sea heat exchanges (Table 3). We assumed a vanishing transport over the narrow continental 
Table 3. Shelf volume transports used in the inversion (positive northward). The transport over the Argentinian shelf is from Saunders and King (1995a). That over the $10 \mathrm{~N}$ shelf was estimated from the shipborne ADCP. The Amazon River transport is from DeMaster and Pope (1996).

$\begin{array}{cccccc} & \begin{array}{c}\text { Argentinian } \\ \text { shelf }\end{array} & 35 \mathrm{~S} & 13 \mathrm{~S} & 10 \mathrm{~N} & \begin{array}{c}\text { Amazon } \\ \text { River }\end{array} \\ \text { Shelf volume transports (Sv) } & 2 \pm 1 & -3 \pm 1 & 0 & 3.5 \pm 1 & 0.2 \pm 0.1\end{array}$

shelf inshore of 13S. For lack of information on the shelf transports at $35 \mathrm{~S}$, we first set them to zero. Observing that this resulted in residuals of opposite signs in the upper layer equations of boxes $\mathrm{S}$ and $\mathrm{C}$, that could be accounted for by a southward shelf transport of $\sim 3 \mathrm{~Sv}$, we then used this value. The shelf tracer transports were estimated as the product of the volume transports and the averaged tracer values in the upper 100 meters of the most inshore stations. The air-sea heat exchanges were estimated from the ECMWF data.

A total of 135 conservation constraints were established, to which we assigned uncertainties that constitute the diagonal matrix $C_{T}$ in Eq. (1).

- A major contribution to the uncertainty of the layer volume equations follows from the neglect of the interfacial transports in these constraints. We assumed typical vertical velocities of $10^{-6} \mathrm{~m} \mathrm{~s}^{-1}$ at the layer interfaces of boxes $\mathrm{S}$ and $\mathrm{C}$, observing that this led to uncertainties (up to $3.5 \mathrm{~Sv}$ in the uppermost layers) not exceeded by the constraint residuals. More difficulty to satisfy the constraints in box $\mathrm{N}$ led us to increase the interfacial velocities to $310^{-6} \mathrm{~m} \mathrm{~s}^{-1}$ in this box, with ensuing uncertainties between $2.5 \mathrm{~Sv}$ and $7 \mathrm{~Sv}$, increasing upward.

- As the contribution of the vertical fluxes was included in the tracer constraints, their uncertainties were computed using an equivalent vertical volume transport lower than that of the volume constraints by one order of magnitude.

- Attempts to account for the neglect of lateral diffusion through increased uncertainties of the tracer equations were abandoned as they did not improve the satisfaction of the volume constraints. Some post-inversion vertical diffusivities ( 3 out of 19 in the selected solution) were negative. As this could result from opposite lateral and vertical diffusive terms with comparable magnitude, we resolved not to force the $K_{v}$ toward positive values, thus renouncing to exploit them.

\section{d. The selected solution}

The last element needed for the inversion is the covariance matrix $C_{0}$, the diagonal of which contains the accepted deviations from the first guess solution. Having observed that the uncertainties on the reference velocities influenced the amplitude of the post-inversion transports while keeping their distribution patterns almost unchanged, we used this parameter to calibrate the solution against concurrent measurements from a current meter array at $18 \mathrm{~S}$, a central latitude of the hydrographic survey. These Eulerian measurements (Weatherly et al., 2000) provide an alongshore transport of $31 \mathrm{~Sv}$ inshore of A17 for the 
deep western boundary current, that was reproduced with reference velocity uncertainties of $1.5 \mathrm{~cm} \mathrm{~s}^{-1}$.

The uncertainties of the equatorial transport unknowns were also chosen from a comparison with direct measurements. These were an ADCP-inferred SACW transport of $19 \mathrm{~Sv}$ out of box $\mathrm{N}$ in the equatorial band, that was indeed used to initialize the solution, and a $7 \mathrm{~Sv}$ AAIW transport inferred from simultaneous measurements along $35 \mathrm{~W}$ by Schott et al. (1998). Equatorial transport uncertainties of $0.1 \mathrm{~Sv}$ in the SACW and $0.3 \mathrm{~Sv}$ below (corresponding to an averaged velocity of $\sim 1 \mathrm{~cm} \mathrm{~s}^{-1}$ over the equatorial band) provided SACW and AAIW transports of $20 \mathrm{~Sv}$ and $10 \mathrm{~Sv}$, respectively, comparable to the $19 \mathrm{~Sv}$ and $7 \mathrm{~Sv}$ reference transports.

The volume transports across A17 obtained with the above parameters and cumulated northward along the line, are displayed in Figure 4 for the five water masses and the whole water column. The light and bold curves are for the a priori and post-inversion solutions, respectively, and the sign convention is positive eastward. Similar curves for the transverse lines are shown in Figure 5. Owing to volume conservation in isopycnal layers, the A17 curves may also be regarded as the latitudinal distributions of the net alongshore transports, positive southward, between A17 and the coast. We verified that this interpretation is also valid for the UCPW, NADW, and LCPW, despite the changes of isopycnal limits of these water masses at the box boundaries, as the transports across the corresponding density steps at $35 \mathrm{~S}$ and $13 \mathrm{~S}$ were all less than $1 \mathrm{~Sv}$. The SACW and total transport curves in Figures 4 and 5 include the Ekman component. As this contribution is weak along A17 (less than $1.3 \mathrm{~Sv}$ westward from $50 \mathrm{~S}$ to the equator, and $3 \mathrm{~Sv}$ eastward from the equator to $10 \mathrm{~N})$, we do not distinguish it from the geostrophic component henceforth.

\section{e. Evaluation of the solution}

A flaw of the selected solution that we could not eliminate is the presence of higher constraint residuals in box $\mathrm{N}$, which indicate an accumulation of water in the upper layers (SACW, AAIW), and a loss in the deep and bottom layers. On running the inversions, our guideline was to reduce the number of residuals exceeding twice the $a$ priori uncertainties to about $10 \%$ of the total number. Of the 14 (out of 135) residuals which exceed this threshold in the selected solution, 12 are from box N, and 2 from box $\mathrm{S}$. The vertical velocities resulting from the imbalance of the lateral transports in box $\mathrm{N}$ reach $710^{-6} \mathrm{~m} \mathrm{~s}^{-1}$ downward at depth, which implies a rate of water mass conversion around $10 \mathrm{~Sv}$ over the surface of this box. Although such a magnitude is comparable to results from other deep budget computations in the equatorial region (Friedrichs et al., 1994; Lux et al., 2000), the sign of the transport (here negative) is opposed to the one found within the NADW in the previous studies. Considering the intense seasonal and intra-seasonal variability of the equatorial circulation at all depths (Johns et al., 1990, 1993, 1998; Schott et al., 1993; Hall et al., 1997; Fischer and Schott, 1997), the high vertical velocities in box N probably reflect an attempt to force a nonsteady real circulation into a stationary model. Several studies concluded in the presence of two-month fluctuations of the currents which, combined with 

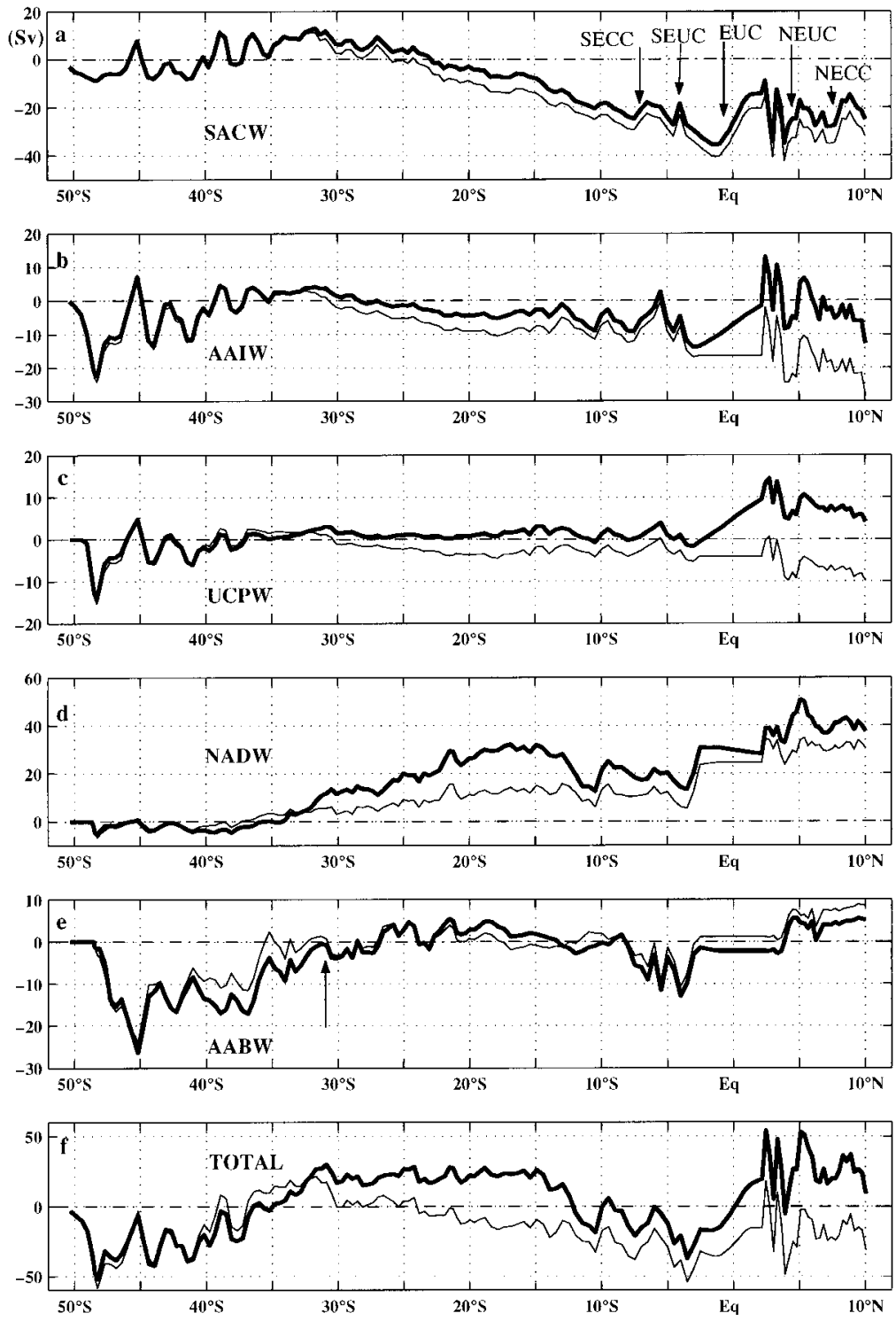

Figure 4. Volume transports cumulated northward along A17, for the five water mass layers (a to e) and the whole water column (f). Transports are positive eastward, and the light and bold curves are for the a priori and post-inversion solutions, respectively. The curves also provide the net alongshore transports between A17 and the coast, positive southward. The signatures of the major eastward equatorial currents are indicated in (a): SECC and NECC (South and North Equatorial Countercurrents), SEUC and NEUC (South and North Equatorial Undercurrents), and EUC (Equatorial Undercurrent). The arrow in (e) shows the $3.5 \mathrm{~Sv}$ throughflow in the Vema Channel. 

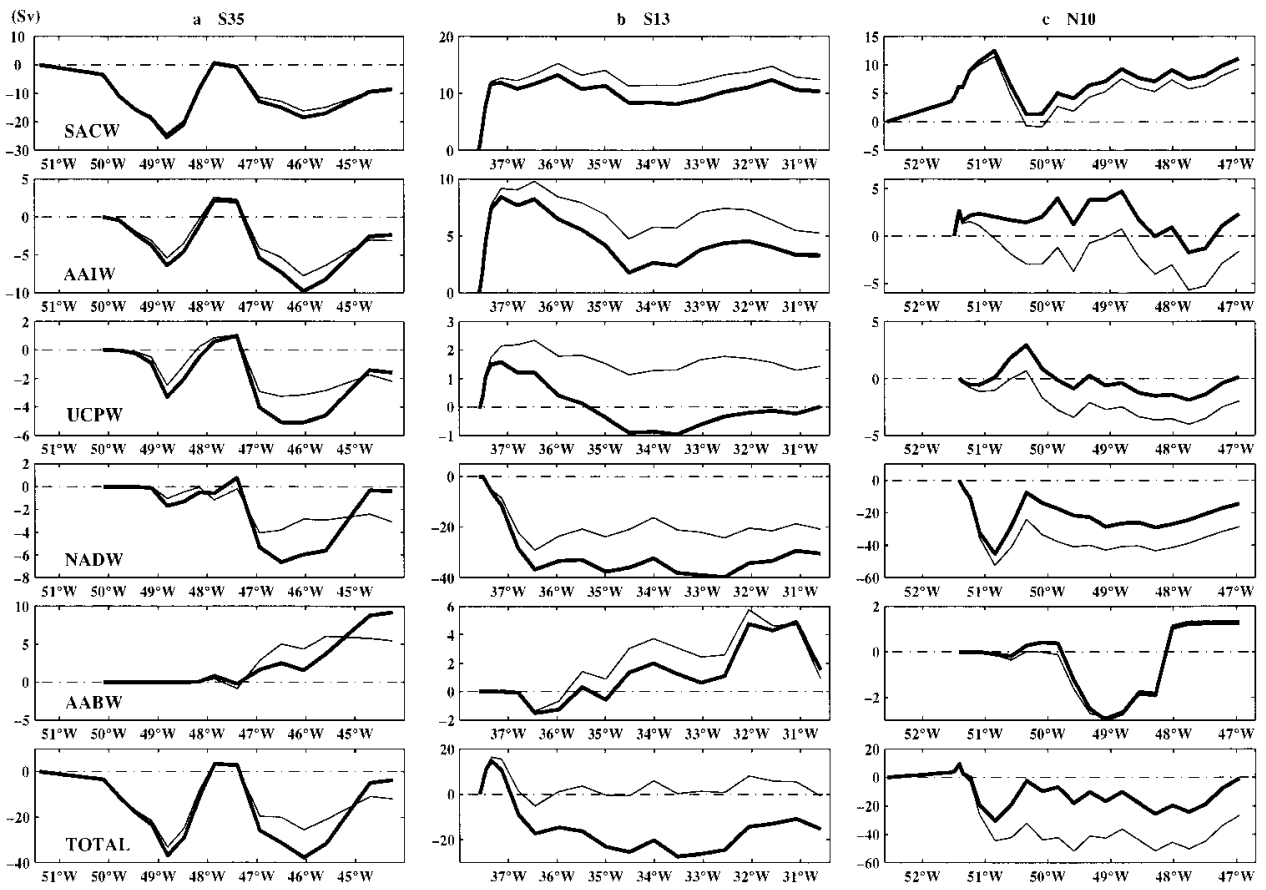

Figure 5. Volume transports cumulated eastward along lines $35 \mathrm{~S}$ (a), 13S (b) and 10N (c), for the five water mass layers and the whole water column. The light and bold curves show the $a$ priori and post-inversion solutions, respectively, and the sign convention is positive northward.

the one-month interval between the sampling of lines $13 \mathrm{~S}$ and $10 \mathrm{~N}$, could explain the only crude conservation of properties in box N. In this box, the solution should, therefore, be regarded as one with minimized, rather than vanishing, transient terms.

We do not present here a detailed study of the solution sensitivity to the a priori choices, which may be found in Wienders (2000). An important choice is naturally that of the $a$ priori solution itself which, as detailed above, was mostly guided by oceanographic considerations based on the literature. There exists, however, several possible combinations of reasonable reference isopycnals in the domain of study. In order to illustrate the solution sensitivity to these choices, we show (Fig. 6) the A17 transports of the selected solution $\left(S_{0}\right)$, and three other solutions $\left(S_{1}, S_{2}, S_{3}\right)$ corresponding to reference isopycnals defined in Table 4. In $S_{1}$, the velocities were referenced at the upper interfaces of the NADW (in boxes $\mathrm{S}$ and C) or MNADW (box N). In $S_{2}$ they were referenced at the lower interfaces of the same water masses. $S_{3}$, finally, corresponds to the deepest choices of all four solutions, namely, the base of the LCPW in boxes S and C, and the base of the LNADW in box N. The constraints were almost equally satisfied by the four solutions, $S_{0}$ being only slightly better for the northern box.

The differences between the four transport curves are minor in the two upper layers. They are more important in the UCPW (locally $5 \mathrm{~Sv}$ ), but do not affect the curve patterns. 

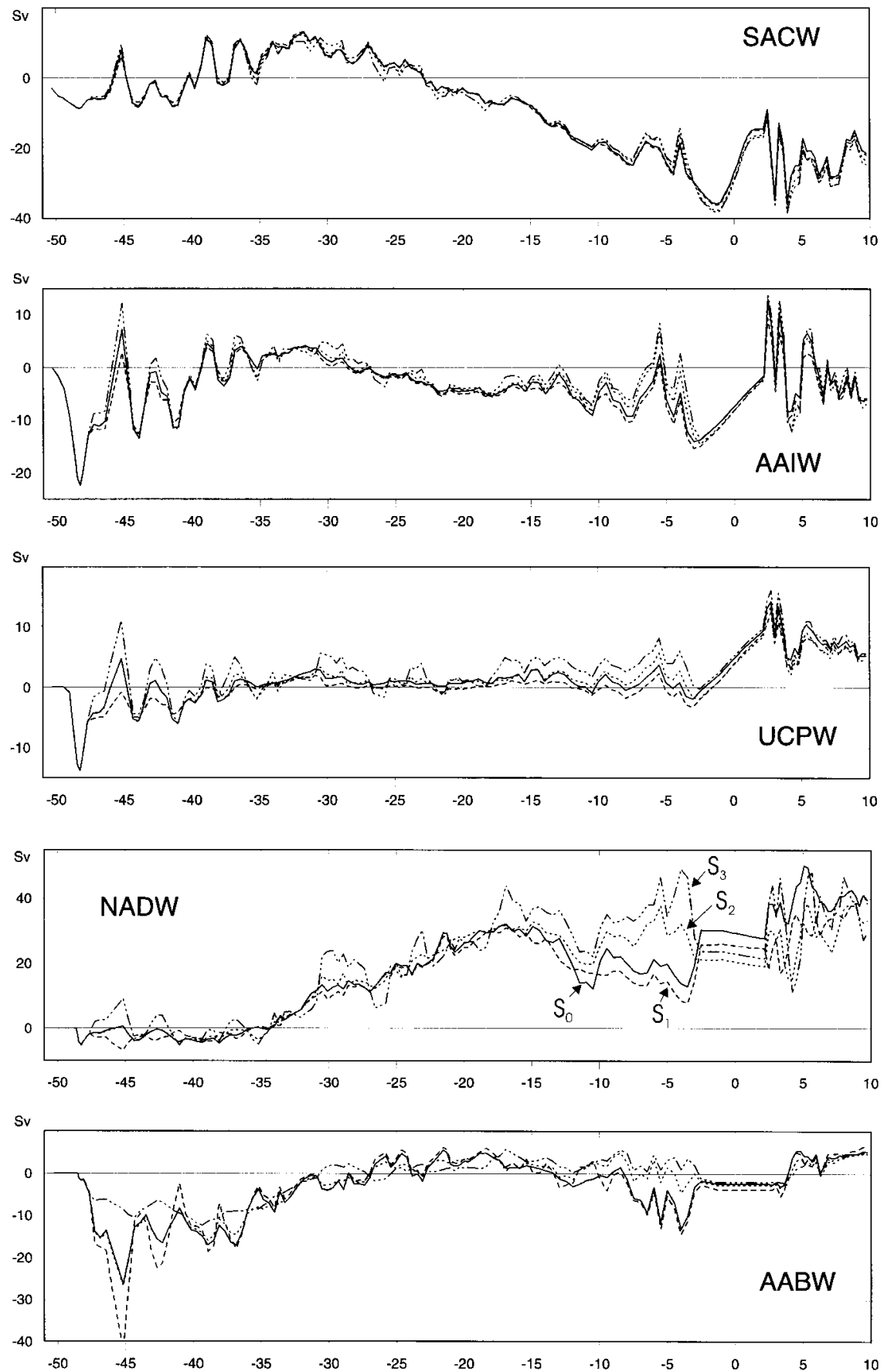

Figure 6. Solution sensitivity to the choice of the reference isopycnals. The curves of cumulated transport are as in Figure 4. The four displayed solutions (defined in Table 4) are recognized in the NADW panel. 
Table 4. A priori choices of reference isopycnals along A17 in the three boxes defined in Figure 1b, for the selected solution $\left(S_{0}\right)$ and the three other solutions shown in Figure 6.

S

$\begin{array}{ll}\mathrm{S}_{0} & 45.87 \sigma_{4} \\ \mathrm{~S}_{1} & 36.88 \sigma_{2} \\ \mathrm{~S}_{2} & 45.87 \sigma_{4} \\ \mathrm{~S}_{3} & 46.04 \sigma_{4}\end{array}$

$\mathrm{C}$

$$
\begin{gathered}
36.83 \sigma_{2}, 45.87 \sigma_{4} \\
36.83 \sigma_{2} \\
45.87 \sigma_{4} \\
46.04 \sigma_{4}
\end{gathered}
$$

$\mathrm{N}$

$45.90 \sigma_{4}, 36.98 \sigma_{2}$

$41.49 \sigma_{3}, 41.45 \sigma_{3}$

$36.98 \sigma_{2}$

$41.49 \sigma_{3}$

$45.90 \sigma_{4}$

In the NADW and AABW layers, local differences on the flow direction itself allow us to discard some reference isopycnals. Those of $S_{2}$ and $S_{3}$ between $2^{\circ} 30^{\prime} \mathrm{S}$ and $4 \mathrm{~S}$, and that of $S_{1}$ between $2^{\circ} 30^{\prime} \mathrm{N}$ and $4 \mathrm{~N}$, which generate flows of NADW opposite to what the observations reveal, are inappropriate. At other places, differences of amplitudes, though significant, do not allow us to decide which solution should be retained. Such is the case for the AABW transport in the Argentine Basin, which amounts to $15 \mathrm{~Sv}-20 \mathrm{~Sv}$ in $S_{0}, S_{1}$ and $S_{2}$ (ignoring the peak at $45 \mathrm{~S}$ which is due to an eddy), and $10 \mathrm{~Sv}-12 \mathrm{~Sv}$ in $S_{3}$. In the selected solution, we favoured the idea that both AABW components (LCPW and WSDW) move in the same direction, but recognize that this is not an absolute criterion.

Our helplessness to carry out a thorough exploration of all physically acceptable solutions impedes the determination of error bars for the transports. However, if we eliminate the $15 \mathrm{~S}-2^{\circ} 30^{\prime} \mathrm{S}$ portions of $S_{1}$ and $S_{2}$ in Figure 6, which lead to unrealistic flow patterns of NADW and AABW, the inversion results appear generally robust. Their mutual compatibility may be quantified to within $5 \mathrm{~Sv}$, except for the AABW in the Argentine Basin, and the NADW north of the equator, where the discrepancies locally reach $10 \mathrm{~Sv}$.

\section{The exchanges of upper and intermediate water across A17}

\section{a. The three bands of the South Equatorial Current}

The denomination South Equatorial Current designates a broad westward flow across the South Atlantic and into the western boundary layer. Molinari (1982) pointed out the subdivision of the flow into three bands, by the eastward South Equatorial Countercurrent at 7S-9S, and the South Equatorial Undercurrent at 3S-5S. Stramma (1991) extended the study of the southern current band southward to $24 \mathrm{~S}$, but regretted the absence of meridional sections reaching farther south for a complete sampling of the flow.

From Figure 4, a transport of $38 \mathrm{~Sv}$ of SACW enters the western boundary between $31^{\circ} 40^{\prime} \mathrm{S}$, the latitude which marks the center of the subtropical gyre along A17, and $7^{\circ} 30^{\prime} \mathrm{S}$, the southern limit of the South Equatorial Countercurrent. As $9 \mathrm{~Sv}$ of AAIW and $2 \mathrm{~Sv}$ of UCPW are also flowing westward (south of $\sim 20 \mathrm{~S}$ where the flow reverses in these layers), a transport estimate of the southern band of the South Equatorial Current from Figure 4 is therefore $49 \mathrm{~Sv}$. Using hydrographic sections along 30W, Stramma (1991) proposed a nominal value of $20 \mathrm{~Sv}$ for the transport in the upper $500 \mathrm{~m}$ between $20 \mathrm{~S}$ and the South Equatorial Countercurrent. As $500 \mathrm{~m}$ is about the average thickness of the SACW layer 


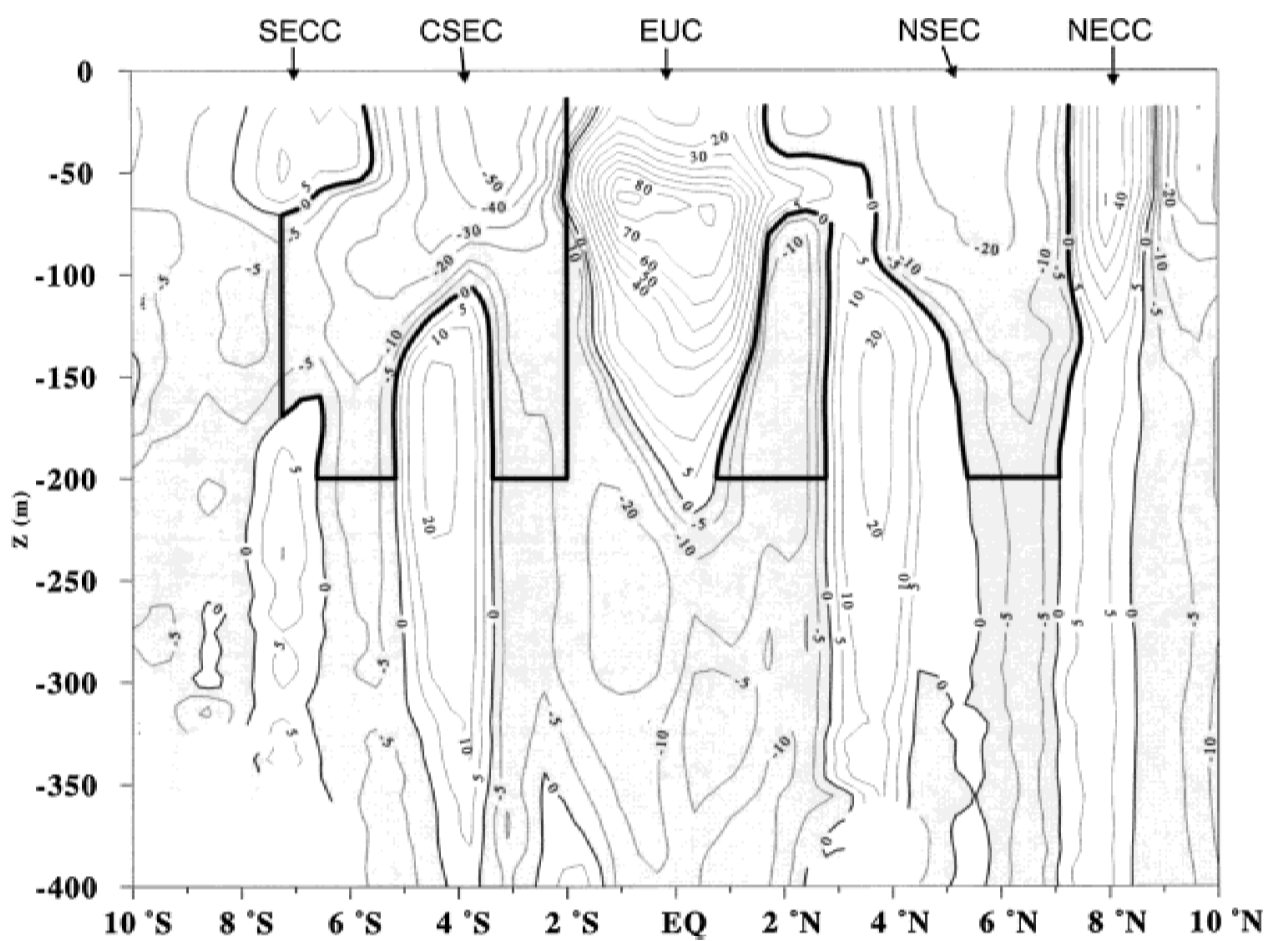

Figure 7. Vertical distribution of the zonal velocity between $10 \mathrm{~S}$ and $10 \mathrm{~N}$ along A17, from the shipborne ADCP, showing the locations of the equatorial currents: SECC and NECC (South and North Equatorial Countercurrents), CSEC and NSEC (central and northern branches of the South Equatorial Current), and EUC (Equatorial Undercurrent). The bold lines show the limits used for the transport computation of the central and northern branches of the South Equatorial Current.

between $7^{\circ} 30^{\prime} \mathrm{S}$ and $20 \mathrm{~S}$ (Fig. 2), the westward transport of $21.7 \mathrm{~Sv}$ for this water mass between the two latitudes is in fair agreement with Stramma's results. The higher estimate of $49 \mathrm{~Sv}$ for the southern branch, therefore, results from our taking into account the southernmost part of the current and the contribution of the intermediate waters.

To the north of the South Equatorial Countercurrent, the interpretation of the SACW and AAIW curves in Figure 4 can no longer be presented in terms of a dominant zonal current, because of the complexity of the equatorial flow regime, and the added disadvantage of the ageostrophic equatorial band. The central and northern branches of the South Equatorial Current are recognized, however, on the vertical distribution of the shipborne ADCP zonal velocity (Fig. 7). As these currents occur within narrow latitudinal regions, their estimation from the ADCP should not lead to prohibitive errors. Having limited them downward at $200 \mathrm{~m}$ or at the boundaries with the underlying South and North Equatorial Undercurrents, their transports were estimated to $17 \mathrm{~Sv}$ and $12 \mathrm{~Sv}$ for the central and northern branches, respectively. The volume transports of the three branches of the South Equatorial Current at the time of $\mathrm{A} 17$ are reported in the first line of Table 5. 
Table 5. The first line shows the volume transports of the southern, central, and northern branches of the South Equatorial Current (SSEC, CSEC, NSEC) at the time of A17. For the central and northern branches only the transports in the upper $200 \mathrm{~m}$ are considered (Fig. 7). The contributions of the subtropical and subequatorial/equatorial domains to the transports are given in the second line. The third line indicates how the transports of the southern and central branches are shared between the boundary currents. BC stands for Brazil Current, NBUC for North Brazil Undercurrent, and NBC for North Brazil Current. From Stramma and England (1999), the fate of the northern branch (not reported) is to feed the North Equatorial Undercurrent and North Equatorial Countercurrent.

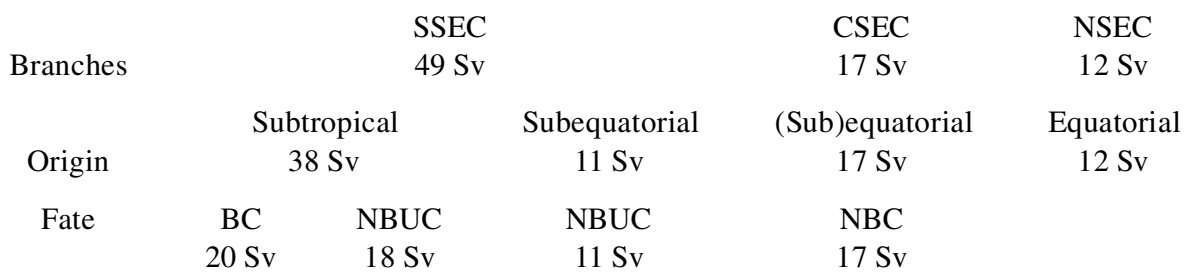

\section{b. The subtropical and subequatorial contributions to the South Equatorial Current}

In their study of the water masses along A17, Mémery et al. (2000) placed the boundary between the oxygen-rich SACW of subtropical origin and the oxygen-poor water from the subequatorial domain at $14 \mathrm{~S}$. Using this latitude in Figure $4 \mathrm{a}, 27 \mathrm{~Sv}$ of the SACW conveyed by the southern branch of the South Equatorial Current can be ascribed to the northern limb of the subtropical gyre, and $11 \mathrm{~Sv}$ to the southern limb of the cyclonic subequatorial gyre. The northern boundary of the subtropical domain in the AAIW is usually placed near 20S (e.g., Warner and Weiss, 1992), the approximate latitude of vanishing westward flow in Figure 4b. In the UCPW the boundary was observed at 26S by Mémery et al. (2000), also near the northern limit of the westward flow in Figure 4c. It ensues that the AAIW and UCPW contributions to the southern band of the South Equatorial Current (9 Sv and $2 \mathrm{~Sv}$, resp.) should be totally ascribed to the subtropical gyre. Adding them to the SACW contribution, the $49 \mathrm{~Sv}$ transport of this branch is composed of $38 \mathrm{~Sv}$ from the subtropical circulation, and $11 \mathrm{~Sv}$ from the subequatorial circulation (Table 5).

Mémery et al. (2000) only observed the tracer contrasts between the subtropical and subequatorial domains in the denser part of the SACW $\left(\sigma_{\theta}>25.8\right)$. The layer $\sigma_{\theta}<25.8$ (Fig. 8a), the depth of which reaches $200 \mathrm{~m}$ in the subtropics, contains the Salinity Maximum Water (SMW) formed at the surface through intense evaporation. Considering from Figure 8a that the formation region of the SMW is the latitude band $25 \mathrm{~S}-8 \mathrm{~S}$ where the surface salinity exceeds 36.6 , the curve of cumulative transports for $\sigma_{\theta}<25.8$ in Figure $8 \mathrm{~b}$ shows that $13 \mathrm{~Sv}$ of this water are conveyed westward by the South Equatorial Current. The SMW region is bounded northward by the South Equatorial Countercurrent. North of this current, a domain of lower salinity $(<36.0)$ extends from $6 \mathrm{~S}$ to $2 \mathrm{~S}$, over the exact latitude range of the central band of the South Equatorial Current (Fig. 7). From Figure 8b, the transport of this band in layer $\sigma_{\theta}<25.8$ (and to the south of $2^{\circ} 30^{\prime} \mathrm{S}$ ) is $12 \mathrm{~Sv}$, i.e. $5 \mathrm{~Sv}$ 

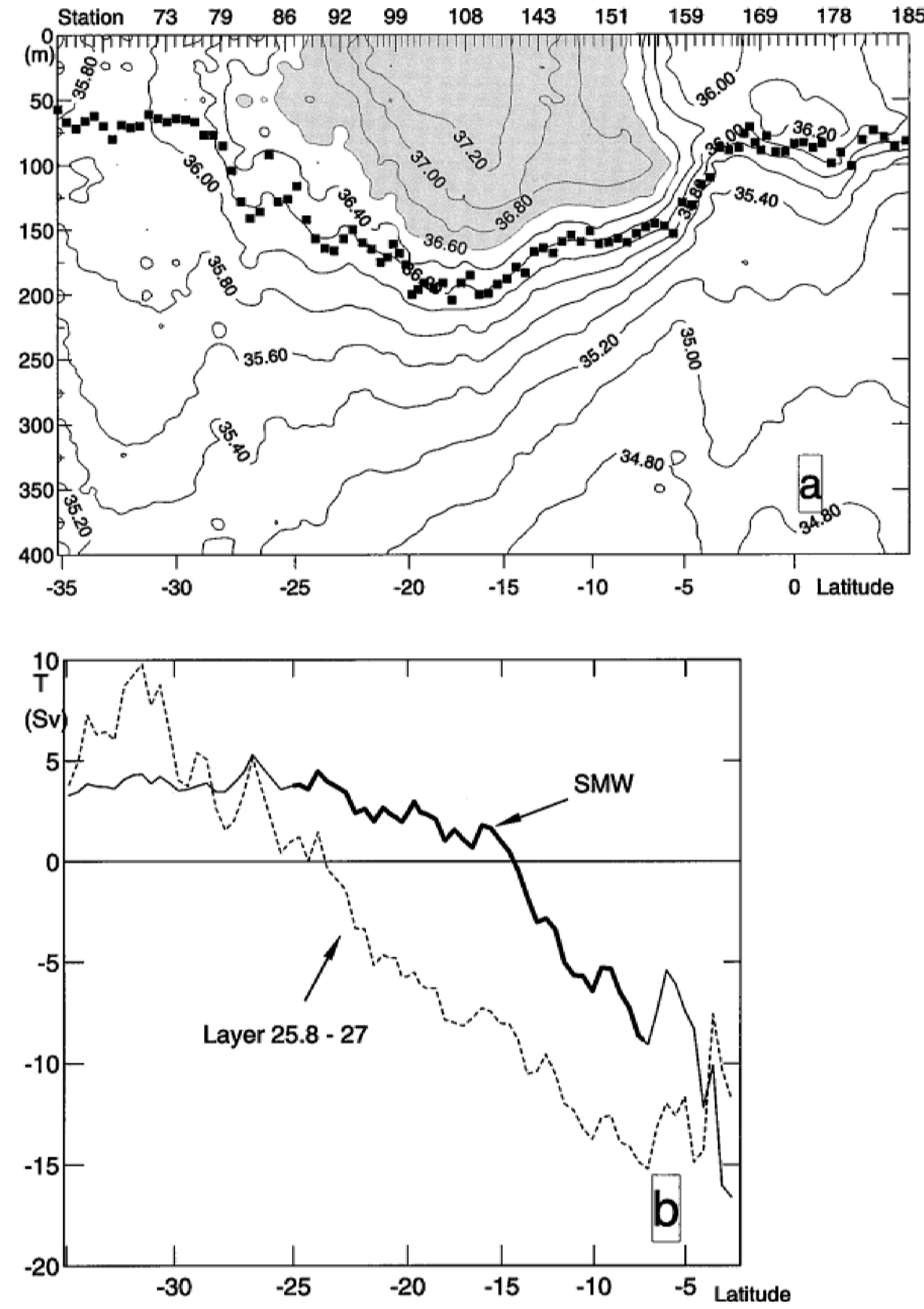

Figure 8. (a) Vertical section of salinity for the upper $400 \mathrm{~m}$ of $\mathrm{A} 17$, from $35 \mathrm{~S}$ to $3 \mathrm{~N}$, showing the Salinity Maximum Water (SMW). The isopycnal $25.8 \sigma_{\theta}$ marking the lower boundary of this water mass is superimposed. (b) Cumulated transport distributions (positive eastward) along A17, in the SMW $\left(\sigma_{\theta}<25.8\right.$; bold line $)$ and in the lower SACW $\left(25.8<\sigma_{\theta}<27.0\right)$. 
lower than the ADCP value reported in Table 5, which was computed using a slightly larger cross-area. The low salinity water transported by this current is most certainly water from the equatorial eastward jets (North Equatorial Countercurrent and Equatorial Undercurrent) that was upwelled and freshened in the ocean interior, before flowing back to the western boundary. Blanke et al. (1999; their Fig. 7a) visualized this basin-wide equatorial gyre using a three-dimensional Lagrangian technique in a numerical model. In their circulation map the central branch of the South Equatorial Current appears as the southern limb of the gyre, indeed bounded southward at $6 \mathrm{~S}-7 \mathrm{~S}$ at $30 \mathrm{~W}$.

\section{c. The vertical structure and bifurcation of the southern branch}

In order to better describe the downward extension of the southern branch of the South Equatorial Current into the AAIW and UCPW layers, we show in Figure 9a the cumulated transports across A17 in $100 \mathrm{~m}$-thick layers, from the surface to $1500 \mathrm{~m}$. The dots on the curves mark the lateral boundaries of the current at each level. Except in the upper $100 \mathrm{~m}$ where an eastward narrow current at $28 \mathrm{~S}$ shifts the southern limit to $27 \mathrm{~S}$, this limit is located at the already quoted latitude $31^{\circ} 40^{\prime} \mathrm{S}$ through most of the sampled layer, with only a slight shift to $30 \mathrm{~S}$ in the UCPW. The northern boundary is at $7^{\circ} 30^{\prime} \mathrm{S}$ above $500 \mathrm{~m}$, then shifts to $18 \mathrm{~S}$ at this depth, a latitude that remains valid down to $750 \mathrm{~m}$ in the upper half of the AAIW layer, and is then progressively displaced to $21 \mathrm{~S}$ at $950 \mathrm{~m}$, at the upper boundary of the UCPW. Further shrinking of the westward current occurs near $1300 \mathrm{~m}$.

Below $600 \mathrm{~m}$, a northward rise of the curves between the north boundary of the southern branch and $12^{\circ} 30^{\prime} \mathrm{S}$ suggests a return flow of lower AAIW and UCPW to the ocean interior. North of the latter latitude, a more irregular pattern with several direction changes prevails. Overall, the zonal AAIW circulation provided by Figure 9a matches the results of Lagrangian experiments at $800 \mathrm{~m}$ depth, which located the northern limit of the subtropical return flow near 20S (Boebel et al., 1999; Ollitrault, 1999).

Several studies of the bifurcation of the South Equatorial Current into the Brazil Current and North Brazil Current at the western boundary have led to the conclusion that the bifurcation latitude is depth-dependent. Although surface velocity measurements (Molinari, 1983) suggested an origin of the Brazil Current at $5^{\circ} 30^{\prime} \mathrm{S}$ near the northeastern tip of Brazil, these northernmost reaches of the current are now considered a mere Ekman layer contribution, the geostrophic component being now thought to start south of 10S (Stramma et al., 1990). The origin of the North Brazil Current was accordingly also displaced southward and, as its subsurface intensification beneath the incipient Brazil Current became clearer (Silveira et al., 1994), this current was re-named «North Brazil Undercurrent» to the south of $5^{\circ} 30^{\prime}$ S (Stramma et al., 1995). The denomination «North Brazil Current» is still used north of this latitude where the undercurrent is over-rided by the central band of the South Equatorial Current. At intermediate depths, Lagrangian measurements have located the bifurcation near $28^{\circ} \mathrm{S}$ (Boebel et al., 1997). The general southward shift of the bifurcation with increasing depth is illustrated in a three-layer schematic flow representation in Stramma and England (1999). 
The zero-crossings of the curves of cumulated transport in isopycnal layers show the latitudes where the alongshore transports between the coast and A17 reverse. These latitudes may be regarded as the locations of origin of the opposed boundary currents, provided that the alongshore transports are mainly due to these currents. A specific cause of uncertainty may reside in the distance of A17 from the coast and a slight northwestward orientation of the South Equatorial Current (Stramma and England, 1999). The ensuing southward shift of the estimated bifurcation location, relative to the actual one nearer the coast, should not exceed 2 to 3 degrees of latitude. For a detailed study of the bifurcation latitude, we defined twelve isopycnal layers over the range $\sigma_{\theta}<27.6$ (which occupies the upper $1200 \mathrm{~m}$ at 20S), and show in Figure 9b their cumulated transport curves.

An important meridional shift of the bifurcation stands out in the SACW, from $14 \mathrm{~S}$ at the surface, to $27 \mathrm{~S}$ in the $26.9-27.07 \sigma_{\theta}$ layer. The latitude change is particularly pronounced in the SMW $\left(\sigma_{\theta}<25.8\right)$. From Figure $8 b$, the average bifurcation latitude for this water mass is $15^{\circ} \mathrm{S}$ and, of the $13 \mathrm{~Sv}$ of it that enter the western boundary layer, $9 \mathrm{~Sv}$ are entrained equatorward in the North Brazil Undercurrent, while $4 \mathrm{~Sv}$ flow southward in the Brazil Current. Below the SMW, the bifurcation occurs at $23 \mathrm{~S}$ in the lower part of the SACW (Fig. 9b). Figure 8b shows that the incoming $25 \mathrm{~Sv}$ of lower SACW $\left(25.8<\sigma_{\theta}<27.0\right)$ in the southern branch of the South Equatorial Current subdivide into a northbound branch of $15 \mathrm{~Sv}$ and a southbound branch of $10 \mathrm{~Sv}$. Considering the SACW as a whole, the $38 \mathrm{~Sv}$ of this water mass conveyed by the south branch of the South Equatorial Current feed the Brazil Current and North Brazil Undercurrent by amounts of $13 \mathrm{~Sv}$ and $25 \mathrm{~Sv}$, respectively.

The bifurcation latitude in the AAIW and UCPW $\left(\sigma_{\theta}>27.07\right.$ in Fig. 9b) is nearly constant at $26 \mathrm{~S}-28 \mathrm{~S}$. The southward transports of AAIW and UCPW are $4 \mathrm{~Sv}$ and $2 \mathrm{~Sv}$ from Figure 4. The AAIW contribution to the North Brazil Undercurrent is $9 \mathrm{~Sv}$ if one considers the latitude band $28 \mathrm{~S}-7^{\circ} 30^{\prime} \mathrm{S}$, but only $5 \mathrm{~Sv}$ if one considers the southern branch proper, to the south of 20S. Although there is no indication of a northward bifurcation of UCPW from Figure 4, the better vertical resolution provided by Figure 9b suggests that a part of the water less dense than $27.5 \sigma_{\theta}$ turns equatorward. All the denser UCPW turns southward at the continental slope in the same direction as the underlying NADW.

Summing up the transports of the three water masses, the third line of Table 5 shows how the southern and central bands of the South Equatorial Current are distributed into the opposed boundary flows. With reference to the thermohaline circulation, a comparison of this line with the second line of the same table allows us to infer the fraction of the South Equatorial Current that eventually contributes to the export of warm water to the North Atlantic. Only considering the northbound parts of the transport, we observe that the fraction of it that has an equatorial or subequatorial origin corresponds to recirculations of the western boundary currents in these regions, and consequently does not contribute to the net northward transport. After subtraction of these low-latitude contributions, we are left with the $18 \mathrm{~Sv}$ subtropical supply to the North Brazil Undercurrent. Although this value should only be considered a rough estimate of the effective transport of the South 


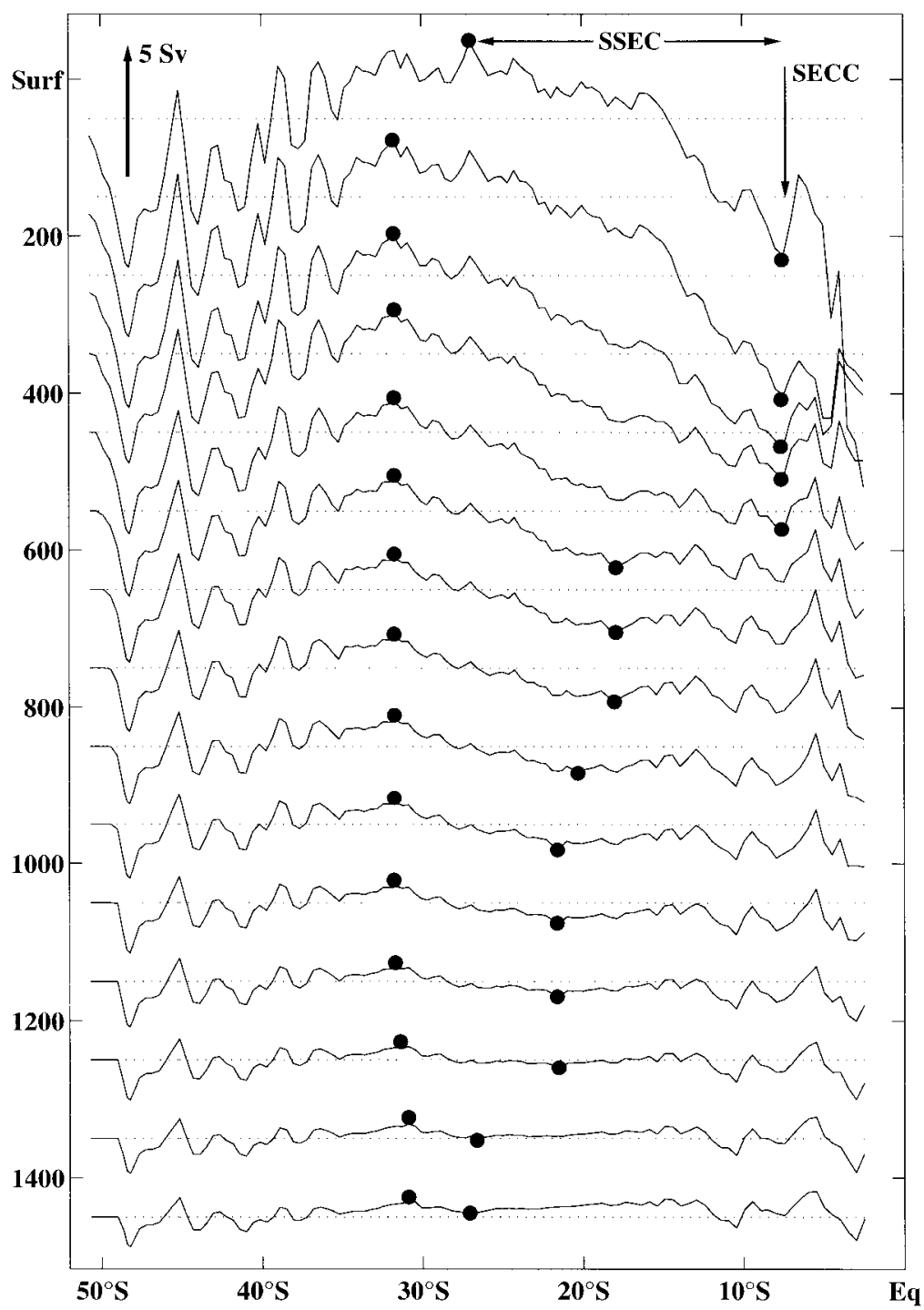

Figure 9. (a) Cumulated transport distributions (positive eastward) in $100 \mathrm{~m}$-thick layers along A17, from the surface to $1500 \mathrm{~m}$ depth. The dots mark the southern and northern boundaries of the southern band of the South Equatorial Current (SSEC) in each layer. The vertical arrow shows the location of the South Equatorial Countercurrent (SECC).

Equatorial Current for the thermohaline circulation, it falls within the range of previous estimates of the warm water export to the North Atlantic: $13 \mathrm{~Sv}-15 \mathrm{~Sv}$ by Schmitz and McCartney (1993); $15.9 \mathrm{~Sv}$ at $14^{\circ} 30^{\prime} \mathrm{N}$ by Klein et al. (1995); and $22 \mathrm{~Sv}$ at $7^{\circ} 30^{\prime} \mathrm{N}$ by Lux et al. (2000). 


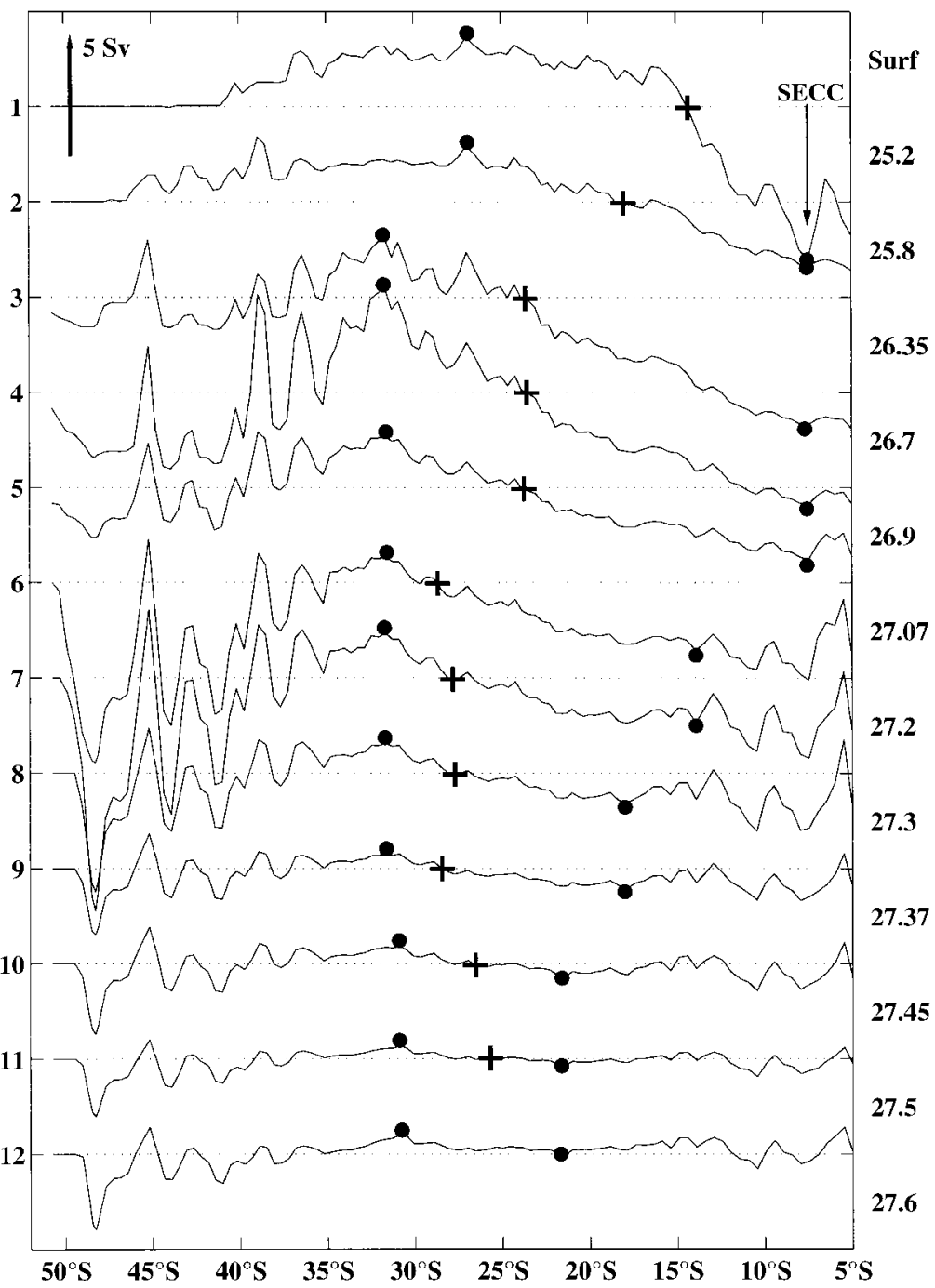

Figure 9. (b) Cumulated transport distributions in twelve isopycnal layers. The dots show the lateral boundaries of the southern band of the South Equatorial Current and the plus signs at the zero-crossing points give the latitudes of the current bifurcation. The interfaces were determined by requiring each layer to be $100 \mathrm{~m}$-thick at $20 \mathrm{~S}$. The layer numbers at the left ordinate axis, therefore, give the depths (in hectometers) of the layer bottom interfaces at this latitude. The right ordinate axis gives the interface densities. 


\section{Deep water exchanges across $\mathbf{A} 17$}

\section{a. Considering the deep water as a whole}

The southward transport of NADW between the northern end of A17 at $10 \mathrm{~N}-49 \mathrm{~W}$, and the coast, is $37 \mathrm{~Sv}$ from Figure 4. Considering that this location is equally distant from the continental slope of French Guiana and the crest of the Mid-Atlantic Ridge, such a transport is compatible with a scheme of Schmitz and McCartney (1993) that shows a southeastward flow of $34 \mathrm{~Sv}$ in the western part of the Guiana Basin, half compensated by a northwestward transport of $17 \mathrm{~Sv}$ in the eastern part. The alongshore transport of NADW between A17 and the coast at the equator is $29 \mathrm{~Sv}$. Rhein et al. (1995) found $26.8 \mathrm{~Sv} \pm$ $7 \mathrm{~Sv}$ across $35 \mathrm{~W}$ in the vicinity of the equator, but mentioned the presence of a variable flow component offshore of the boundary current proper (and inshore of A17), that hinders the comparison. Adjacent to the equatorial band on either side are two eastward jets that bring down the net southward transport of NADW between A17 and the coast to $14 \mathrm{~Sv}$ at $3^{\circ} 30^{\prime} \mathrm{S}$. The northern and southern jets have transports of $10 \mathrm{~Sv}$ and $17 \mathrm{~Sv}$, respectively. The existence of these flows between two and three degrees of latitude in either hemisphere was noticed by Mémery et al. (2000) from their density and oxygen signatures along A17, and by Richardson and Fratantoni (1999) from Lagrangian measurements at a depth of $1800 \mathrm{~m}$.

The region between $3^{\circ} 30^{\prime} \mathrm{S}$ and $17 \mathrm{~S}$ has a net westward transport of $19 \mathrm{~Sv}$, only interrupted at $10 \mathrm{~S}$ by a $10 \mathrm{~Sv}$ eastward flow. Examination of the oxygen section (Fig. 2a) reveals a correspondence between the regions of westward flow and two patterns of lower oxygen $\left(<250 \mu \mathrm{mol} \mathrm{kg}{ }^{-1}\right)$ at $3^{\circ} 30^{\prime} \mathrm{S}-9^{\circ} 30^{\prime} \mathrm{S}$ and $11 \mathrm{~S}-19 \mathrm{~S}$. Similar features were present in the 25W section of Tsuchiya et al. (1994), and in other neighboring data discussed by Reid (1989). This author interpreted this breach in the tongue of NADW as a westward intrusion of water with circumpolar characteristics, a view that is confirmed here. Float displacements at 2500 m-depth in Hogg and Owens (1999) also shows a westward flow between $3 \mathrm{~S}$ and $17 \mathrm{~S}$. As the higher oxygen pattern at $10 \mathrm{~S}$ is also present at $25 \mathrm{~W}$ (Tsuchiya et al., 1994), it probably marks an eastward escape of NADW at this latitude. Figure 4 suggests a pronounced barotropic character of this current, which is observed in the vicinity of the Pernambuco Seamounts, located inshore of A17 between $8^{\circ} 30^{\prime} \mathrm{S}$ and $10 \mathrm{~S}$.

The finding by Weatherly et al. (2000) of a transport in excess of $30 \mathrm{~Sv}$ for the deep western boundary current at $18 \mathrm{~S}$, when compared with the generally accepted estimates of about $20 \mathrm{~Sv}$ at the equator, suggested the presence of an offshore recirculation to enhance the boundary flow. Weatherly et al. (2000), having observed no significant northward recirculation of NADW adjacent to the boundary current, suggested that the required flow should take place farther east in the ocean interior. They looked in vain for a high oxygen signature in a zonal section at $18 \mathrm{~S}$, and concluded that the recirculating water could only be NADW that had flowed far south along the continental slope, and mixed with lower oxygen southern water. Our observation, from Figures 4 and 2, that the reinforcement of the southward transport between $11^{\circ} \mathrm{S}$ and $15^{\circ} \mathrm{S}$ results from an inflow of lower oxygen deep water, bears out their conclusion. It also fits in with a large-scale circulation pattern at 
$2500 \mathrm{~m}$ depth in Reid (1989; his Fig. 23), in which a broad northward flow is visible around 20W at 20S, issued from the Argentine Basin with a contribution of the Falkland Current, and a return to the western boundary at $11 \mathrm{~S}-17 \mathrm{~S}$. From an analysis of a section at $24 \mathrm{~S}$, Warren and Speer (1991) favor a positioning of the northward current over the eastern flank of the Mid-Atlantic Ridge.

A net eastward flow of $36 \mathrm{~Sv}$ of NADW takes place between 17S and 38S across A17 (Fig. 4d). The decrease of the deep water curve over this latitudinal band is almost regular, except for a $4 \mathrm{~Sv}$ peak at $21 \mathrm{~S}$ near the Vitoria-Trindade Ridge, a plateau from $27 \mathrm{~S}$ to $31 \mathrm{~S}$, and a steeper slope indicative of enhanced current between $31 \mathrm{~S}$ and 34S. The negative values to the south of the latter latitude reveal a net equatorward transport between A17 and the continental slope, that should be ascribed to a dominant contribution of circumpolar water against NADW. The already mentioned circulation map of Reid (1989) at $2500 \mathrm{~m}$ actually shows a northward flow just offshore of the boundary current in the Argentine Basin, fed with Drake Passage water in addition to NADW from the boundary flow. The NADW panel of Figure 5a illustrates the two opposed flows at 35S (of equal magnitude at this latitude).

\section{b. The three components of the NADW}

The deep water transports discussed so far refer to the NADW layer defined in Table 1, whose isopycnic boundaries vary southward to account for the increased presence of circumpolar water in the original NADW density range. In order to get more details on the behavior of the individual NADW components (upper, middle and lower), and see how the transition to the southern waters occurs, we now discuss the transports in the isopycnic layers of the three varieties, in relation with the meridional oxygen distribution in each layer (Fig. 10). For this analysis we refer to the three layers as to the Upper, Middle, and Lower Deep Waters (UDW, MDW, LDW), in recognition of the fact that they contain waters other than NADW.

In the Guiana Basin, a net $6 \mathrm{~Sv}$ shoreward transport of UDW from $10 \mathrm{~N}$ to $2^{\circ} 30^{\prime} \mathrm{N}$ contrasts with opposite flows of MDW ( $8 \mathrm{~Sv}$ ) and LDW (9 Sv). A comparable flow of UDW to the western boundary at these latitudes was inferred by Rhein et al. (1995) from transport computations at $44 \mathrm{~W}$ and $35 \mathrm{~W}$. The exchanges of UDW across A17 show a pronounced spatial variability, though. We observe, in particular, a $16 \mathrm{~Sv}$ shoreward jet at $3 \mathrm{~N}-4 \mathrm{~N}$ which resembles a flow at $3 \mathrm{~N}-5 \mathrm{~N}$ that was obtained by Richardson and Fratantoni (1999) from their $1800 \mathrm{~m}$-deep float trajectories. Another pronounced change of direction is present in the three varieties near the Ceara Rise $(\sim 5 \mathrm{~N})$. The eastward jet at $2^{\circ} 30^{\prime} \mathrm{N}-3 \mathrm{~N}$ discussed above results from contributions of the UDW and MDW only. Although an intense eastward current $(11 \mathrm{~Sv})$ also stands out in the LDW, it is located slightly more to the north, between $3^{\circ} 30^{\prime} \mathrm{N}$ and $5 \mathrm{~N}$. As these latitudes mark the southeastern boundary of the Guiana Basin (Fig. 2), it is likely that most of the LDW seen crossing A17 there feeds the northwestward recirculation in the eastern part of the basin.

The highest contribution to the eastward jet of NADW at $2^{\circ} 30^{\prime} \mathrm{S}-3^{\circ} 30^{\prime} \mathrm{S}$ is that of the 
Sv $\left(\mu \mathrm{mol} \mathrm{kg}{ }^{-1}\right)$
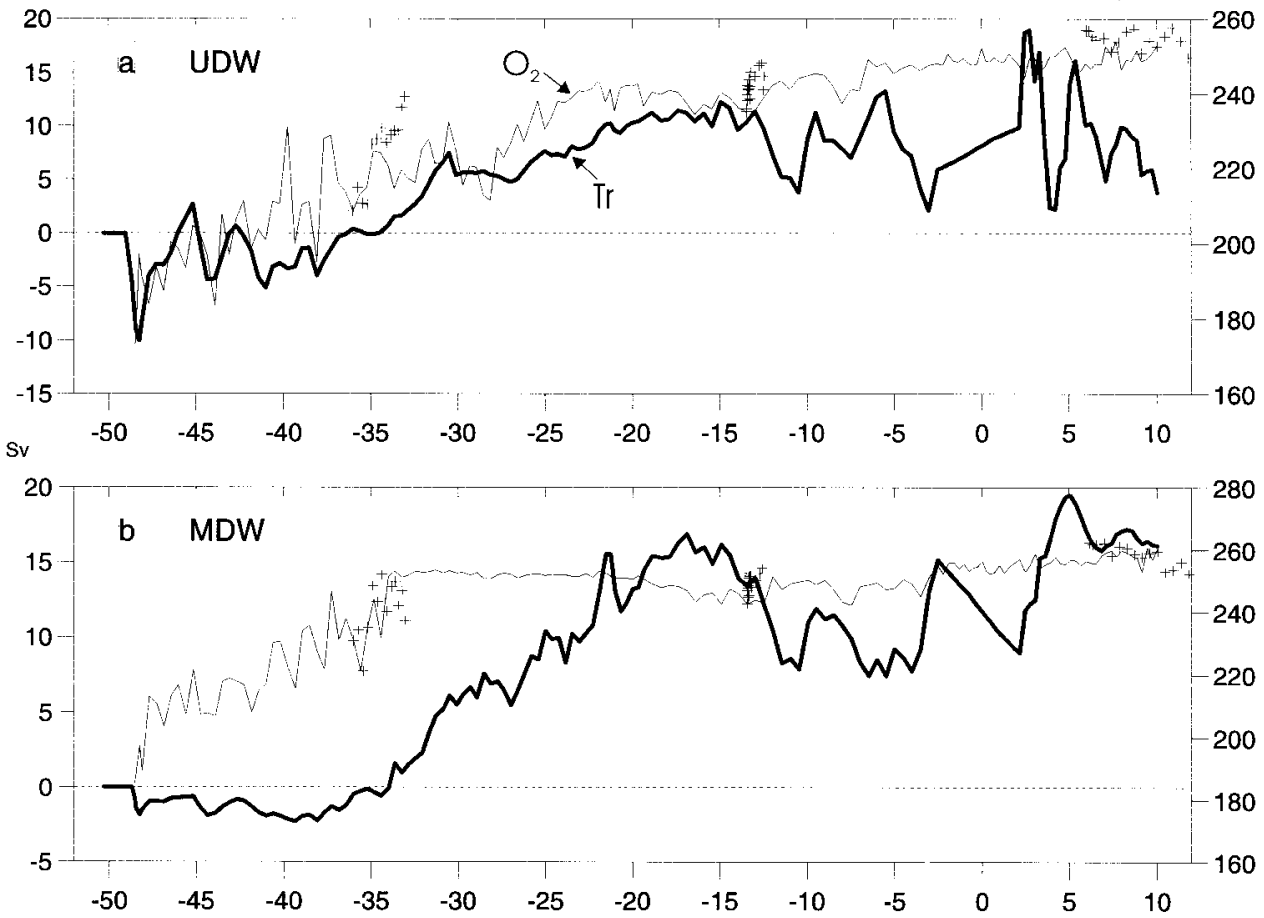

Sv

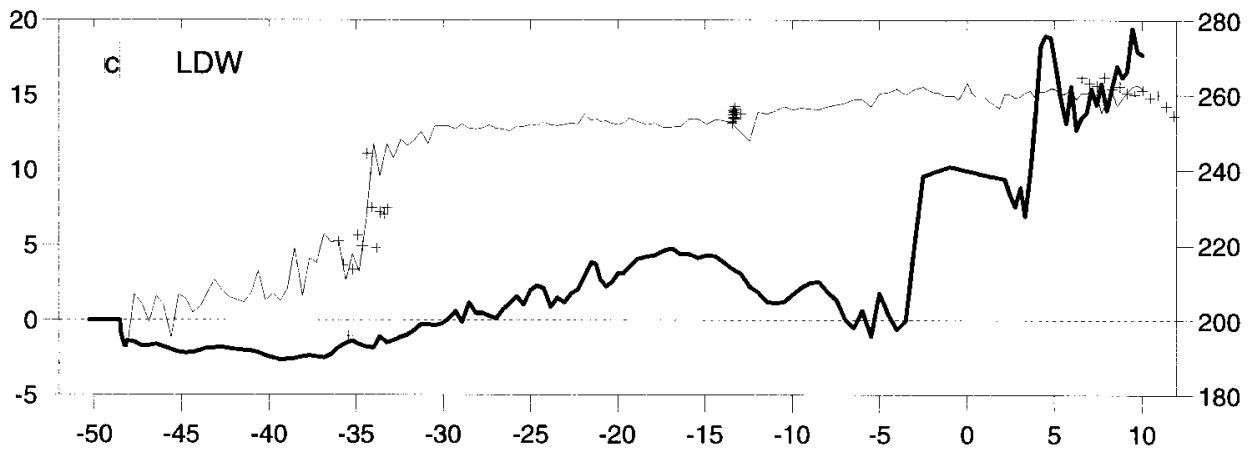

Figure 10. Cumulated transports positive eastward (bold) and isopycnal oxygen (thin) distributions in the three deep water sublayers: (a) Upper Deep Water $\left(32.2<\sigma_{1,2}<36.98\right)$ : Oxygen distribution along $36.9 \sigma_{2}$. (b) Middle Deep Water $\left(36.98<\sigma_{2,3}<41.49\right)$ : Oxygen distribution along $41.45 \sigma_{3}$. (c) Lower Deep Water $\left(41.49<\sigma_{3,4}<45.90\right)$ : Oxygen distribution along $45.86 \sigma_{4}$. The plus signs show the oxygen values along the same isopycnals on the transverse lines $35 \mathrm{~S}, 13 \mathrm{~S}$, and $10 \mathrm{~N}$.

LDW, which amounts to $10 \mathrm{~Sv}$. The eastward flow of LNADW toward the entry of the Romanche Fracture Zone was traced by Speer and McCartney (1991), and Friedrichs et al. (1994) found a transport of $7 \mathrm{~Sv}$ for it. A consequence of our finding a higher value here is a vanishing of the net southward transport of LDW between A17 and the coast, at $4 \mathrm{~S}$. This 


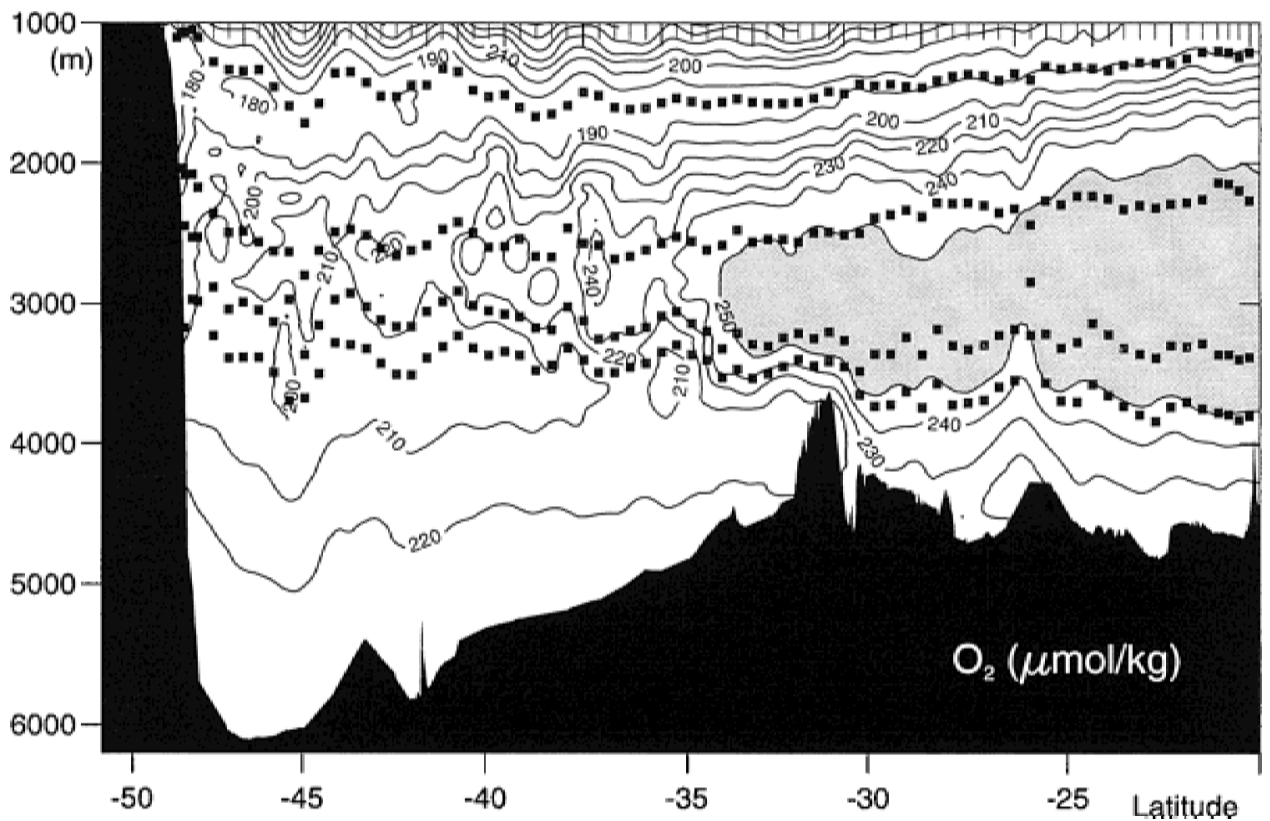

Figure 11. Deep vertical distribution of dissolved oxygen from $50 \mathrm{~S}$ to $20 \mathrm{~S}$, for visualization of the transition from NADW to Circumpolar Water. The isopycnal boundaries of the three deep sublayers are superimposed $\left(32.2 \sigma_{1}, 36.98 \sigma_{2}, 41.49 \sigma_{3}, 45.90 \sigma_{4}\right)$.

result (probably uncertain to within a few Sverdrups) does not imply a vanishing of the boundary current itself, as an opposite equatorward flow may be present between it and A17. Nevertheless, it corroborates previous low estimates of the boundary current of LDW downstream of the equatorial bifurcations: $1 \mathrm{~Sv}$ in Friedrichs et al. (1994), and 1 to $3 \mathrm{~Sv}$ in Rhein et al. (1995).

In Figure 10, the transition from the NADW components to waters with significant circumpolar characteristics appears as changes in the slopes of the isopycnic oxygen curves. Except for the limited oxygen decrease associated with the westward flow of diluted NADW between $4 \mathrm{~S}$ and $17 \mathrm{~S}$, the northernmost latitude where the southern influence is felt is near $21^{\circ} \mathrm{S}$ in the UDW layer (Fig. 10a). In order to better examine this transition region, we show in Figure 11 an expanded view of its vertical oxygen distribution, with the isopycnic boundaries of the three deep layers superimposed. Using the isopleth $\mathrm{O}_{2}=200 \mu \mathrm{mol} \mathrm{kg}-1$ as a boundary between the UCPW and NADW, this figure shows the diminishing amount of UCPW from 50S to 20S. First considering the UDW layer, we observe that the density range $32.2<\sigma_{1,2}<36.98$ of the UNADW at $10 \mathrm{~N}$ is also that of the core of UCPW at its entry in the Argentine Basin in the Falkland Current. This inflow of UCPW (marked by oxygen values lower than $180 \mu \mathrm{mol} \mathrm{kg}{ }^{-1}$ ) amounts to $10 \mathrm{~Sv}$ (Fig. 10a), a transport equal to that of the southward flow of UNADW at 20S. Although the apparent confluence between the opposite currents occurs at the zero-crossing latitude $35 \mathrm{~S}$ 
along A17, no sharp oxygen front marks this location. The gradual transition from one water mass to the other over the range $48 \mathrm{~S}-21 \mathrm{~S}$ is explained by two factors. First, the NADW boundary current proceeds along the continental slope to the real Brazil-Falkland confluence at $\sim 38$ S (Maamaatuaiahutapu et al., 1992). At this location it is entrained in the return Falkland Current and partially mixed with UCPW. The intersection of the Falkland return flow at $48 \mathrm{~S}-45 \mathrm{~S}$ by A17 explains an already detectable NADW influence at these latitudes $\left(\mathrm{O}_{2}>190 \mu \mathrm{mol} \mathrm{kg}{ }^{-1}\right)$. The other reason lies in the entrainment of UCPW in the subtropical gyre, and its re-entry in the western boundary layer at subtropical latitudes. This westward flow is visible from $31 \mathrm{~S}$ to $27 \mathrm{~S}$ in Figure 10a, that is, in the narrow deepest part of the South Equatorial Current (Fig. 9a). A local oxygen minimum marks this current.

The transition from the northern to the southern component in the MDW layer (Fig. 10b) contrasts with the above description in that the oxygen curve now exhibits a pronounced front at $34 \mathrm{~S}$, the very zero-crossing latitude of the transport curve. The possibility for the water to keep its northern signature as far south as $34 \mathrm{~S}$ reflects the absence of the South Equatorial Current at this level. South of the front, on the other hand, the transition is progressive, for the same reason as evoked for the overlying layer, i.e., injection of NADW characteristics in the Falkland return current. The negative transports to the south of $34 \mathrm{~S}$ reveals a northward flow of the mixed water, and eventual exit toward the ocean interior alongside the uncontaminated NADW present north of this latitude. The unmixed character of the MNADW to the north of the front suggests a recent bifurcation from the boundary current, in agreement with an enhanced eastward transport at 30S-34S in Figure 10b. Eulerian measurements at $2300 \mathrm{~m}-2500 \mathrm{~m}$ depth above the Santos Plateau, presented by Hogg and Owens (1999; their Fig. 3c), show this bifurcation. Deeper in the water column, the oxygen front also stands out in the LDW layer, with a still more pronounced character (Fig. 10c). At variance with the MDW layer, however, there is no correspondence with the zero-crossing latitude of the transport curve, which is now $30 \mathrm{~S}$.

\section{Bottom water transports}

Before presenting the cumulated transports of $\mathrm{AABW}$, we discuss the intense negative peak at $-26 \mathrm{~Sv}$ present at $45 \mathrm{~S}$ in their meridional distribution (Fig. 4e). In order to check this feature, we compared our AABW transports with those found by Saunders and King (1995b) along a zonal section at 45S. Their results show a cumulative transport of $5 \mathrm{~Sv}$ at the intersection of the two hydrographic lines, clearly incompatible with our high value. An intense Brazil Current eddy present at this location (Fig. 2b), and our use of a mid-depth a priori level of no motion inappropriate to this mesoscale feature, caused the peak in Figure 4. Whereas the density signature of this eddy suggests a full-depth anticyclonic motion, the mid-depth reference surface produces an abyssal cyclonic flow which, added to the larger scale cyclonic circulation, causes the intense negative value. Disregarding the peak, the AABW transport at the base of the Falkland Current has an intensity of $15 \mathrm{~Sv}$ from 50S to 47S, still higher than the estimate of Saunders and King (1995b). The interval between $47 \mathrm{~S}$ and $45 \mathrm{~S}$, and their use of a deeper reference surface $\left(45.96 \sigma_{4}\right)$ are likely 
causes of the remaining difference. The effect of a deeper reference isopycnal on the AABW transports is illustrated by solution $S_{3}$ in Figure 6.

The region from $44 \mathrm{~S}$, at the northern edge of the eddy, to 37S, has a weak net shoreward transport of AABW across A17, in accordance with a circulation scheme in Coles et al. (1996) which shows a southwestward flow in this area, nearly aligned with A17. The transports of $\mathrm{AABW}$ in and out of the boundary layer almost exactly compensate over the latitudinal span of the Argentine Basin, with only $0.5 \mathrm{~Sv}$ left to flow northward over the Santos Plateau at $31^{\circ} 15^{\prime} \mathrm{S}$. This result matches the transport computations of Hogg et al. (1999), which led these authors to conclude that «there is little, if any, net flow (of AABW) over the plateau». The hydrographic line intersected the Vema Channel at $30^{\circ} 30^{\prime} \mathrm{S}$. A 3.5 Sv inflow of AABW into the Brazil Basin is visible at this latitude (marked by an arrow in Fig. 4e), a value slightly lower than the 4 Sv estimate of Hogg et al. (1999). On Figure 4e, the Vema Channel flow is hardly noticeable in a broader southeastward transport of $22.5 \mathrm{~Sv}$ from $37 \mathrm{~S}$ to $21^{\circ} 30^{\prime} \mathrm{S}$, the latitude of the Vitoria-Trindade Ridge. The general flow direction reverses to the north of this ridge, with a net westward transport of $18.5 \mathrm{~Sv}$ from $19^{\circ} \mathrm{S}$ to $4 \mathrm{~S}$. An eastward exit of $11 \mathrm{~Sv}$ at the northwestern corner of the Brazil Basin finally leaves $2 \mathrm{~Sv}$ of $\mathrm{AABW}$ to flow over the Equatorial Channel into the Guiana Basin. In this basin, the overflow joins with a $5 \mathrm{~Sv}$ southward flow to the west of A17 for a $7 \mathrm{~Sv}$ northeastward exit across the line at $4 \mathrm{~N}$.

The positive cumulated transports on the AABW curve between $27 \mathrm{~S}$ and $13^{\circ} 30^{\prime} \mathrm{S}$ were a surprise to us, as we had not expected that more AABW would leave the western boundary layer, than had entered it in the south. Several trials with different a priori solutions (Fig. 6), with an artificial increase of the Falkland Current, or with the abyssal boxes (BS, BC, BN) not used, led to solutions also exhibiting the positive values. Although the possibility for a totally negative AABW curve with other inversion parameters should not be excluded, this result suggests that a fraction $(5.5 \mathrm{~Sv})$ of the water that enters the western boundary between $19 \mathrm{~S}$ and $4 \mathrm{~S}$ turns southward along the continental slope, until it rejoins the Vema Channel outflow in a $\sim 6.5 \mathrm{~Sv}$ eastward exit near $27 \mathrm{~S}$, at the location of the southernmost zero-crossing. We emphasize that a net southward transport over the AABW density range and inshore of A17 does not imply the absence of a northward bottom boundary current. It means that, in the considered latitude range, this northward flow is dominated by a southward transport of other AABW components. The northward bottom flow is indeed visible through its tracer signatures in a zonal section near $18^{\circ} \mathrm{S}$ presented by Durrieu de Madron and Weatherly (1994; their Fig. 3b). In their section, however, most of the cold water $\left(\theta<0.2^{\circ} \mathrm{C}\right)$ which marks the northward flow is observed to the east of $31 \mathrm{~W}$, the longitude of A17. Conversely, there are recent indications of a poleward boundary flow in the AABW density range at such latitudes. Hogg and Owens (1999) report southward float trajectories at $4000 \mathrm{~m}$ depth on either side of the Vitoria-Trindade Ridge, and the Eulerian measurements of Weatherly et al. (2000) at $18 \mathrm{~S}$ show a bottom-reaching southward boundary current, with a transport of $4 \mathrm{~Sv}$ in the AABW layer. A combination of the two effects, the eastward shift of the abyssal equatorward flow, on the one hand, and the 
downward extension of the poleward deep boundary current, on the other hand, might be the reason for the net southward transport of AABW inshore of $\mathrm{A} 17$ at $13^{\circ} 30^{\prime} \mathrm{S}-27 \mathrm{~S}$.

\section{Summary}

The solution that we retained (considered as representative of the period January-March 1994) is admittedly not unique, and subject to defects that are more pronounced in the equatorial region. Although the high number of inversion parameters makes it difficult to quantify the absolute errors of the transport estimates, the concordance between numerous local results and the larger scale view provided by this study is an a posteriori confirmation of its general correctness.

In the upper and intermediate layers, the southern, central, and northern bands of the South Equatorial Current had transports of $49 \mathrm{~Sv}, 17 \mathrm{~Sv}$, and $12 \mathrm{~Sv}$, respectively, at the period of the cruise. Excluding the part of the southern band that bifurcates southward at the western boundary, and the parts of the three bands (recognized from lower salinity or oxygen values) that have recirculated in the equatorial and subequatorial regions, the transport that effectively contributes to the thermohaline circulation was estimated at $18 \mathrm{~Sv}$, a value comparable to previous estimates of the export of warm water to the North Atlantic.

At the NADW level, the signature of the well-known Guiana Basin recirculation was observed on the A17 transports. In the southern hemisphere, our results are compatible with the idea of a northward recirculation of a blend of NADW and circumpolar deep water from $50^{\circ} \mathrm{S}$ to the vicinity of the equator (Reid, 1989; Warren and Speer, 1991). Embedded in this large-scale circulation is a westward flow of mixed water in the northern part of the Brazil Basin that reinforces the transport of the deep western boundary current between $4 \mathrm{~S}$ and $17 \mathrm{~S}$ (from $14 \mathrm{~Sv}$ to $31 \mathrm{~Sv}$ ). In this layer, the A17 analysis also suggests that significant separations from the western boundary, each amounting to $\sim 12 \mathrm{~Sv}$, occur at $30 \mathrm{~S}-34 \mathrm{~S}$ and 10S. The former is located to the north of a sharp oxygen front which marks the boundary with the recirculating diluted NADW. The latter, although recognized on other hydrographic data, would probably require confirmation.

The transports of AABW show two cyclonic circulation patterns, one of $15 \mathrm{~Sv}$ in the western Argentine Basin (of lower magnitude in other solutions, though), and one of $13 \mathrm{~Sv}$ in the northwestern Brazil Basin. These magnitudes, compared with those of the flows that connect the abyssal basins (7 Sv through the Vema and Hunter channels according to Zenk et al., 1999; and $2 \mathrm{~Sv}$ over the Equatorial Channel), are indicative, in this layer also, of significant recirculations in both basins. The $7 \mathrm{~Sv}$ estimate of the AABW cyclonic circulation in the Guiana Basin is lower. The alongshore transport of AABW inshore of A17 is southward from $13 \mathrm{~S}$ to $27 \mathrm{~S}$, with a narrow interruption near $22 \mathrm{~S}$. A partial shift of the equatorward boundary current of $\mathrm{AABW}$ to the east of the hydrographic line, and the influence of the overlying poleward flow of NADW, may explain this result. The opposed alongshore transports on either side of $13 \mathrm{~S}$ are fed by a broad shoreward transport of $18 \mathrm{~Sv}$ between $19 \mathrm{~S}$ and $4 \mathrm{~S}$, a latitude range that nearly coincides with that of the overlying 
westward flow of recirculated NADW, and suggests a coupling of the deep and bottom large-scale circulations in the Brazil Basin.

In the Introduction we emphasized the role of a meridional guide that the western boundary plays for both the warm and cold waters of the thermohaline circulation. While the results naturally confirm this view, the A17 sampling also exhibits the signatures of perturbations to the thermohaline flows that are caused by recirculations at sub-basin scales throughout the water column. In the upper and intermediate layers, these recirculations are related to the wind-driven gyres. The bathymetric configuration of the abyssal sub-basins, through a blocking of the densest waters, and ensuing vertical forcing, probably causes the AABW recirculations. At the deep levels, the reasons for the northward return of diluted NADW from the southern Argentine Basin to subequatorial latitudes are more obscure.

Acknowledgments. This investigation was supported by IFREMER (Grant 210161), INSU (Institut National des Sciences de l'Univers), and the CNRS, in the framework of the Programme National d'Etude de la Dynamique du Climat (PNEDC), and its WOCE/France subprogramme. N. Wienders' contribution was done while he was a student at the Laboratoire de Physique des Oceans, supported by an IFREMER Grant. We are grateful to two anonymous reviewers whose suggestions and detailed comments helped us improve the manuscript. We also thank L. Mémery (coordinator and chief scientist of cruise CITHER-2), M. Ollitrault, and G. Weatherly for useful discussions. The aid of J. Le Gall and Ph. Le Bot in the preparation of the manuscript is acknowledged.

\section{REFERENCES}

Blanke, B., M. Arhan, G. Madec and S. Roche. 1999. Warm water paths in the equatorial Atlantic as diagnosed with a general circulation model. J. Phys. Oceanogr., 29, 2753-2768.

Boebel, O., C. Schmid and W. Zenk. 1997. Flow and recirculation of Antarctic Intermediate Water across the Rio Grande Rise. J. Geophys. Res., 102, C9, 20967-20986.

- 1999. Kinematic elements of Antarctic Intermediate Water in the western South Atlantic. Deep-Sea Res. II, 46, 355-392.

Bourlès B., Y. Gouriou and R. Chuchla. 1999. On the circulation in the upper layer of the western equatorial Atlantic. J. Geophys. Res., 104, C9, 21151-21170.

Broecker, W. S. 1974. «NO», a conservative water mass tracer. Earth Planet. Sci. Lett., 23, 100-107.

Coles, V. L., M. S. McCartney, D. B. Olson and W. M. Smethie. 1996. Changes in Antarctic Bottom Water properties in the western South Atlantic in the late 1980s. J. Geophys. Res., 101, C4, 8957-8970.

DeMaster, D. J. and R. H. Pope. 1996. Nutrient dynamics in Amazon shelf waters: Results from AMASSEDS. Continental Shelf Res., 16, 263-289.

Durrieu de Madron, X. and G. Weatherly. 1994. Circulation, transport and bottom boundary layers of the deep currents in the Brazil Basin. J. Mar. Res., 52, 583-638.

Equipe ETAMBOT (l'). 1997. Campagne ETAMBOT-2, Recueil de données. Documents scientifiques du Centre ORSTOM de Cayenne, NO.P.24, 1997.

Fischer, J. and F. Schott. 1997. Seasonal transport variability of the Deep Western Boundary Current in the equatorial Atlantic. J. Geophys. Res., 102, C13, 27751-27769.

Friedrichs, M. A., M. S. McCartney and M. M. Hall. 1994. Hemispheric asymmetry of deep water transport modes in the western Atlantic. J. Geophys. Res., 99, C12, 25165-25179.

Groupe CITHER-2 (Le). 1995. Recueil de données, campagne CITHER-2, R/V MAURICE EWING (4 janvier-21 mars 1994). Volume 2: CTD-O2. Rapport Interne LPO 95-04, 520 pp. 
Groupe CITHER-2 (Le). 1996. Recueil de données, campagne CITHER-2, R/V MAURICE EWING (4 janvier-21 mars 1994). Volume 1: Mesure «en route», paramètres météorologiques, bathymétrie et courantométrie Doppler. Rapport Interne LPO 96-01, 180 pp.

Hall, M. M., M. McCartney and J. A. Whitehead. 1997. Antarctic Bottom Water flux in the equatorial western Atlantic. J. Phys. Oceanogr., 27, 1903-1926.

Hogg, N. G. and W. B. Owens. 1999. Direct measurements of the deep circulation within the Brazil Basin. Deep-Sea Res. II, 46, 335-353.

Hogg, N. G., G. Siedler and W. Zenk. 1999. Circulation and variability at the southern boundary of the Brazil Basin. J. Phys. Oceanogr., 29, 145-157.

Johns, W. E., D. M. Fratantoni and R. J. Zantopp. 1993. Deep western boundary current variability off northeastern Brazil. Deep-Sea Res., 40, 293-310.

Johns, W. E., T. N. Lee, R. C. Beardsley, J. Candela, R. Limeburner and B. Castro. 1998. Annual cycle and variability of the North Brazil Current. J. Phys. Oceanogr., 28, 103-128.

Johns, W. E., T. N. Lee, F. A. Schott, R. J. Zantopp and R. H. Evans. 1990. The North Brazil Current retroflection seasonal structure and eddy variability. J. Geophys. Res., 95, C12, 22103-22120.

Klein, B., R. L. Molinari, T. J. Müller and G. Siedler. 1995. A transatlantic section at 14.5N: Meridional volume and heat fluxes. J. Mar. Res., 53, 929-957.

Lux, M., H. Mercier and M. Arhan. 2001. Interhemispheric exchanges of mass and heat in the Atlantic ocean in January-March 1993. Deep Sea Res. I, 48, 605-638.

Maamaatuaiahutapu, K., V. C. Garçon, C. Provost, M. Boulahlid and A. P. Osiroff. 1992. BrazilMalvinas Confluence: Water mass composition. J. Geophys. Res., 97, C6, 9493-9505.

McCartney, M. S. and R. Curry. 1993. Transequatorial flow of Antarctic Bottom Water in the western Atlantic Ocean: Abyssal geostrophy at the equator. J. Phys. Oceanogr., 23, 1264-1276.

Mémery, L., M. Arhan, X. A. Alvarez-Salgado, M.-J. Messias, H. Mercier, C. G. Castro and A. F. Rios. 2000. The water masses along the western boundary of the South and Equatorial Atlantic. Prog. Oceanogr. 47, 69-98.

Molinari, R. L. 1982. Observations of eastward currents in the tropical south Atlantic Ocean: 1978-1980. J. Geophys. Res., 87, C12, 9707-9714.

- 1983. Sea-surface temperature and dynamic height distributions in the central tropical South Atlantic Ocean. OceanologicaActa, 6, 29-34.

Ollitrault, M. 1999. MARVOR floats reveal intermediate circulation in the western Equatorial and Tropical South Atlantic $\left(30^{\circ} \mathrm{S}\right.$ to $\left.5^{\circ} \mathrm{N}\right)$. InternationalWOCE Newsletter, 34, 7-10.

Onken, R. 1994. The asymmetry of western boundary currents in the upper Atlantic Ocean. J. Phys. Oceanogr., 24, 928-948.

Peterson, R. G. 1992. The boundary current in the western Argentine Basin. Deep-Sea Res., 39, 623-644.

Peterson, R. G., C. S. Johnson, W. Krauss and R. E. Davis. 1996. Lagrangian measurements in the Malvinas Current, in The South Atlantic: Present and Past Circulation, G. Wefer, W. Berger, G. Siedler, D. Webb, eds., Springer-Verlag, 239-247.

Reid, J. L. 1989. On the total geostrophic circulation of the South Atlantic Ocean: Flow patterns, tracers, and transports. Prog. Oceanogr., 23, 149-244.

Rhein, M. L., L. Stramma and U. Send. 1995. The Atlantic deep western boundary current: water masses and transports near the equator. J. Geophys. Res., 100, C2, 2441-2457.

Richardson, P. L. and D. M. Fratantoni. 1999. Float trajectories in the Deep Western Boundary Current and deep equatorial jets of the tropical Atlantic. Deep-Sea Res. II, 46, 305-333.

Saunders, P. M. and B. A. King. 1995a. Bottom currents derived from a shipborne ADCP on WOCE cruise A11 in the South Atlantic. J. Phys. Oceanogr., 25, 329-347.

1995b. Oceanic fluxes on the WOCE A11 section. J. Phys. Oceanogr., 25, 1942-1958. 
Schmitz, W. J. and M. McCartney. 1993. On the North Atlantic circulation. Rev. of Geophys., 31, $29-49$.

Schott, F., J. Fischer, J. Reppin and U. Send. 1993. On mean and seasonal currents and transports at the western boundary of the equatorial Atlantic. J. Geophys. Res., 98, C8, 14353-14368.

Schott, F. A., J. Fischer and L. Stramma. 1998. Transports and pathways of the upper layer circulation in the western tropical Atlantic. J. Phys. Oceanogr., 28, 1904-1928.

Silveira da, I. C. A., L. B. de Miranda and W. S. Brown. 1994. On the origins of the North Brazil Current. J. Geophys. Res., 99, C11, 22501-22512.

Speer, K. G. and M. S. McCartney. 1991. Tracing lower North Atlantic Deep Water across the equator. J. Geophys. Res., 96, C11, 20443-20448.

Stommel, H. 1957. A survey of ocean current theory. Deep-Sea Res., 4, 149-184.

Stramma, L. 1991. Geostrophic transport of the South Equatorial Current in the Atlantic. J. Mar. Res., 49, 281-294.

Stramma, L. and M. England. 1999. On the water masses and mean circulation of the South Atlantic Ocean. J. Geophys. Res., 104, 20863-20883.

Stramma, L., J. Fischer and J. Reppin. 1995. The North Brazil Undercurrent. Deep-Sea Res., 42, 773-795.

Stramma, L., Y. Ikeda and R. G. Peterson. 1990. Geostrophic transport in the Brazil Current region north of $20^{\circ}$ S. Deep-Sea Res., 37, 1875-1886.

Tarentola, A. and B. Valette. 1982. Generalized nonlinear problems solved using the least squares criterion. Rev. Geophys., 20, 219-232.

Tsuchiya, M., L. D. Talley and M. S. McCartney. 1994. Water-mass distributionsin the western South Atlantic: A section from South Georgia Island (54S) northward across the equator. J. Mar. Res., 52, $55-81$.

Veronis, G. 1978. Model of world ocean circulation:III. Thermally and wind driven. J. Mar. Res., 36, $1-44$.

Vivier, F. and C. Provost. 1999. Direct velocity measurements in the Malvinas Current. J. Geophys. Res., 104, C9, 21083-21103.

Warner, M. J. and R. F. Weiss. 1992. Chlorofluoromethanes in the South Atlantic Intermediate Water. Deep-Sea Res. A, 39, 2053-2075.

Warren, B. A. and K. G. Speer. 1991. Deep circulationin the eastern South Atlantic Ocean. Deep-Sea Res., 38, S1, S281-S322.

Weatherly, G. L., Y. Yin Kim and E. A. Kontar. 2000. Eulerian measurements of the North Atlantic Deep Water Deep Western Boundary Current at $18^{\circ}$ S. J. Phys. Oceanogr., 30, 971-986.

Wienders, N. 2000. Bilan de volume dans la couche limite ouest-Atlantique de $50^{\circ} \mathrm{S}$ à $10^{\circ} \mathrm{N}$. Thèse de Doctorat, Université de Bretagne Occidentale, Brest, No 745.

Zenk, W., G. Siedler, B. Lenz and N. G. Hogg. 1999. Antarctic Bottom Water flow through the Hunter Channel. J. Phys. Oceanogr., 29, 2785-2801.

Zenk, W., K. G. Speer and N. G. Hogg. 1993. Bathymetry at the Vema sill. Deep-Sea Res., 40, 1925-1933. 